\title{
Effect of sodium chloride on solute-solvent interactions in aqueous polyethylene glycol-sodium sulfate two-phase systems
}

\author{
Nuno R. da Silva ${ }^{a}$, Luisa A. Ferreira ${ }^{b}$, Pedro P. Madeira ${ }^{c}$, José A. Teixeira ${ }^{a}$, \\ Vladimir N. Uversky ${ }^{\mathrm{d}}$, Boris Y. Zaslavsky ${ }^{\mathrm{b}, *}$ \\ a CEB-Centre of Biological Engineering, University of Minho, 4710-057 Braga, Portugal \\ b Analiza, Inc., 3615 Superior Ave., Cleveland, OH 44114, USA \\ ${ }^{\mathrm{c}}$ Laboratory of Separation and Reaction Engineering, Department of Chemical Engineering, Faculty of Engineering of the University of Porto, \\ Rua Dr. Roberto Frias, 4200-465 Porto, Portugal \\ ${ }^{\mathrm{d}}$ Department of Molecular Medicine, Morsani College of Medicine, University of South Florida, Tampa, FL 33612, USA
}

\section{A R T I C L E I N F O}

\section{Article history:}

Received 5 October 2015

Received in revised form 4 November 2015

Accepted 5 November 2015

Available online 10 November 2015

\section{Keywords:}

Aqueous two-phase system

Partitioning

Proteins

Solute-water interactions

Solvatochromic comparison method

Solvent properties

\begin{abstract}
A B S T R A C T
Partition behavior of eight small organic compounds and six proteins was examined in poly(ethylene glycol)-8000-sodium sulfate aqueous two-phase systems containing $0.215 \mathrm{M} \mathrm{NaCl}$ and $0.5 \mathrm{M}$ osmolyte (sorbitol, sucrose, TMAO) and poly(ethylene glycol)-10000-sodium sulfate- $0.215 \mathrm{M} \mathrm{NaCl}$ system, all in $0.01 \mathrm{M}$ sodium phosphate buffer, $\mathrm{pH}$ 6.8. The differences between the solvent properties of the coexisting phases (solvent dipolarity/polarizability, hydrogen bond donor acidity, and hydrogen bond acceptor basicity) were characterized with solvatochromic dyes using the solvatochromic comparison method. Differences between the electrostatic properties of the phases were determined by analysis of partitioning of sodium salts of dinitrophenylated (DNP-) amino acids with aliphatic alkyl side-chain. The partition coefficients of all compounds examined (including proteins) were described in terms of solute-solvent interactions. The results obtained in the study show that solute-solvent interactions of nonionic organic compounds and proteins in polyethylene glycol-sodium sulfate aqueous two-phase system change in the presence of $\mathrm{NaCl}$ additive.
\end{abstract}

(c) 2015 Elsevier B.V. All rights reserved.

\section{Introduction}

Aqueous two-phase systems (ATPSs) formed in aqueous mixtures of a single polymer and specific salt, such as polyethylene glycol (PEG) and sodium sulfate, phosphate or citrate, are commonly used for separation of proteins and nucleic acids [1]. These ATPSs are inexpensive and have good operational characteristics (low viscosity of the phases, high settling speed) and are easily scaled-up. Extraction in ATPS has been demonstrated as an efficient method for large scale recovery and purification of proteins and nucleic acids [1] as well as various other materials. Design of optimal extraction conditions for any target product remains currently an empirical process, and high throughput methods for screening different separation conditions have been developed $[2,3]$. For rational design of the optimal separation conditions it is important to understand the mechanisms of solute distribution in polymer-salt ATPS at the molecular level.

\footnotetext{
* Corresponding author. Tel.: +1 216432 9050x111.

E-mail address: bz@analiza.com (B.Y.Zaslavsky).
}

One of the factors commonly used for manipulating partition behavior of proteins and nucleic acids in PEG-salt ATPSs is addition of $\mathrm{NaCl}$ [4-15]. The mechanism of effects of relatively small amounts of $\mathrm{NaCl}$ in the ATPS containing large amount of phaseforming salt remains unclear. We reported [16-18] previously that different salt additives $\left(\mathrm{NaCl}, \mathrm{NaH}_{2} \mathrm{PO}_{4}, \mathrm{NaClO}_{4}, \mathrm{NaSCN}\right)$ at the concentrations from $0.027 \mathrm{M}$ up to ca. $1.9 \mathrm{M}$ affect partition behavior of small organic compounds in PEG-sodium sulfate ATPS according to the salt effects on the water structure.

It has been shown [19] recently that solute partitioning in PEGsodium sulfate ATPS is governed by the solute-solvent interactions in the coexisting phases. Partition coefficient of a solute in an ATPS is defined as the ratio of the solute concentration in the top phase to the solute concentration in the bottom phase and may be described as [19]:

$\log K=S_{s} \Delta \pi *+B_{s} \Delta \alpha+A_{s} \Delta \beta+C_{S} C$

where $K$ is the solute partition coefficient; $\Delta \pi^{*}, \Delta \alpha, \Delta \beta$ and $c$ are the differences between the solvent properties of the top and bottom phases (solvent dipolarity/polarizability, hydrogen-bond donor acidity, hydrogen-bond acceptor basicity, and electrostatic 
interactions, respectively); $S_{s}, B_{s}, A_{s}$, and $C_{s}$ are constants (solutespecific coefficients) that describe the complementary interactions of the solute with the solvent media in the coexisting phases; the subscript 's' designates the solute.

The differences between the solvent dipolarity/polarizability, $\Delta \pi^{*}, \Delta \alpha^{*}$, hydrogen-bond donor acidity, $\Delta \alpha$, hydrogen-bond acceptor basicity, $\Delta \beta$, may be quantified with solvatochromic dyes [19]. The difference between the electrostatic properties of the phases may be determined by analysis of the partition coefficients of a homologous series of sodium salts of dinitrophenylated (DNP-) amino acids with aliphatic alkyl side-chains $[19,20]$. It has been shown that for a given compound (including proteins) the solute-specific coefficients may be determined by multiple linear regression analysis of the partition coefficients of the compound in multiple ATPSs with the same ionic composition.

The purpose of the present work was to explore the effect of $\mathrm{NaCl}$ additive on partitioning of different solutes in PEG- $\mathrm{Na}_{2} \mathrm{SO}_{4}$ ATPS in terms of solute-solvent interactions. It has been shown [19] previously that the solvatochromic dyes may be used for analysis of the solvent properties of the phases in PEG-sodium sulfate ATPS with $\mathrm{NaCl}$ additive in the concentration range from 0 to $0.54 \mathrm{M}$. We selected the $\mathrm{NaCl}$ concentration of $0.215 \mathrm{M}$, and examined partitioning of eight different organic compounds and six proteins in several PEG- $\mathrm{Na}_{2} \mathrm{SO}_{4}-0.215 \mathrm{M} \mathrm{NaCl}$ ATPSs in the presence of different osmolytes (sorbitol, sucrose, and trimethylamine $\mathrm{N}$-oxide) previously established [19] to affect solvent properties of the phases but not to engage in direct interactions with the solutes being partitioned.

\section{Experimental}

\subsection{Materials}

Polyethylene glycol-8000 (Lot 091M01372V) with an average molecular weight $\left(M_{w}\right)$ of 8,000 and polyethylene glycol10000 (Lot 043K2522) with an average molecular weight $\left(M_{w}\right)$ of 10,000 were purchased from Sigma-Aldrich (St. Louis, MO, USA). The solvatochromic probes 4-nitrophenol (reagent grade, $>98 \%$ ) was purchased from Aldrich (Milwaukee, WI, USA) and 4-nitroanisole (>97\%, GC) was received from Acros Organics. Reichardt's carboxylated betaine dye, 2,6-diphenyl-4[2,6-diphenyl-4-(4-carboxyphenyl)-1-pyridino]phenolate, sodium salt was kindly provided by Professor C. Reichardt (Philipps University, Marburg, Germany).

Sorbitol and trimethylamine N-oxide (TMAO) were purchased from Sigma-Aldrich, and sucrose was received from USB (Cleveland, OH, USA). Benzyl alcohol, caffeine; coumarin, methyl anthranilate, 4-nitrophenyl- $\alpha$-D-glucopyranoside, phenol, 2-phenylethanol, vanillin, and o-phthaldialdehyde (OPA) reagent (complete) were purchased from Sigma-Aldrich. All compounds were of 98-99\% purity and used as received without further purification. All salts and other chemicals used were of analytical-reagent grade.

\subsubsection{Dinitrophenylated amino acids}

Dinitrophenylated (DNP) amino acids: DNP-glycine, DNPalanine, DNP-norvaline, DNP-norleucine, and DNP- $\alpha$-amino- $n$ octanoic acid, were purchased from Sigma-Aldrich. The sodium salts of the DNP-amino acids were prepared by titration.

\subsubsection{Proteins}

$\alpha$-Chymotrypsin from bovine pancreas, $\alpha$-chymotrypsinogen $\mathrm{A}$ from bovine pancreas, concanavalin A from Canavalia ensiformis (jack beans), lysozyme from chicken egg white, and papain from papaya latex were purchased from Sigma-Aldrich. Porcine pancreatic lipase was purchased from USB Corp. (Solon, OH, USA). All protein samples were characterized by SDS-PAGE electrophoresis in a microfluidic chip using Experion automated electrophoresis station (Bio-Rad, USA) under non-reduced conditions. All proteins were observed as single bands in the electrophoregrams.

\subsection{Methods}

\subsubsection{Aqueous two-phase systems}

Stock solutions of PEG 8000 (50 wt.\%), PEG-10000 (50 wt.\%) and $\mathrm{Na}_{2} \mathrm{SO}_{4}$ (20.3 wt.\%) were prepared in water. Sodium phosphate buffer (NaPB; $0.5 \mathrm{M}$, pH 6.8) was prepared by mixing $3.45 \mathrm{~g}$ of $\mathrm{NaH}_{2} \mathrm{PO}_{4} \cdot \mathrm{H}_{2} \mathrm{O}$ and $3.55 \mathrm{~g} \mathrm{Na} \mathrm{HPO}_{4}$ in $100 \mathrm{~mL}$ aqueous solution. Stock solutions of osmolytes:sorbitol (2M), sucrose (1.8 M), and TMAO $(1.8 \mathrm{M})$, and $\mathrm{NaCl}(5 \mathrm{M})$ were prepared in water. A mixture of PEG-8000 or PEG-10000, buffer, and $\mathrm{NaCl}$ was prepared by dispensing appropriate amounts of the aqueous stock of polymer, $\mathrm{Na}_{2} \mathrm{SO}_{4}$ and $\mathrm{NaPB}$ solutions into a $1.2 \mathrm{~mL}$ microtube using a Hamilton (Reno, NV, USA) ML-4000 four-probe liquid-handling workstation. Appropriate amounts of water and/or stock osmolytes solutions were added to give the required ionic, polymer, and osmolyte composition of the final system with total weight of $0.5 \mathrm{~g}$ (after addition of the solute sample, see below). All aqueous PEG$8000-\mathrm{Na}_{2} \mathrm{SO}_{4}-\mathrm{NaCl}$ two-phase systems had a fixed composition of $11.10 \mathrm{wt} \%$ PEG-8000, $6.33 \mathrm{wt} \% \mathrm{Na}_{2} \mathrm{SO}_{4}, 0.215 \mathrm{M} \mathrm{NaCl}$, and $0.01 \mathrm{M}$ $\mathrm{NaPB}, \mathrm{pH}$ 6.8, with different $0.5 \mathrm{M}$ osmolyte additive. The aqueous PEG-10000- $\mathrm{Na}_{2} \mathrm{SO}_{4}-\mathrm{NaCl}$ two-phase system had the same composition of $11.10 \mathrm{wt} \% \mathrm{PEG}-10000,6.33 \mathrm{wt} \% \mathrm{Na}_{2} \mathrm{SO}_{4}, 0.215 \mathrm{M} \mathrm{NaCl}$, and $0.01 \mathrm{M}$ NaPB, pH 6.8 .

\subsubsection{Partitioning experiments}

The aqueous two-phase partitioning experiments were performed using an Automated Signature Workstation, ASW (Analiza, Cleveland, OH, USA). The ASW system is based on the ML-4000 liquid-handling workstation (Hamilton Company) integrated with a FL600 fluorescence microplate reader (Bio-Tek Instruments, Winooski, VT, USA) and a UV-vis microplate spectrophotometer (SpectraMax Plus384, Molecular Devices, Sunnyvale, CA, USA). Solutions of all organic compounds were prepared in water at concentrations of $2-5 \mathrm{mg} / \mathrm{mL}$ depending on the compound solubility. Solutions of all proteins were prepared in water at concentrations of $1-5 \mathrm{mg} / \mathrm{mL}$. Varied amounts $(0,15,30,45,60$, and $75 \mu \mathrm{L})$ of a given compound solution and the corresponding amounts $(75,60$, $45,30,15$, and $0 \mu \mathrm{L}$ ) of water were added to a set of the same polymer/buffer mixtures with and without osmolyte additives. The systems were then vortexed in a Multi-pulse Vortexer and centrifuged for $60 \mathrm{~min}$ at $3500 \times \mathrm{g}$ at $23^{\circ} \mathrm{C}$ in a refrigerated centrifuge (Hettich Universal 320R, Germany) to accelerate phase settling. The upper phase in each system was partially removed, the interface discarded, and aliquots from the upper and lower phases were withdrawn in duplicate for analysis.

For the analysis of organic compounds partitioning, aliquots of $50-120 \mu \mathrm{L}$ from both phases were diluted up to $600 \mu \mathrm{L}$ in $1.2 \mathrm{~mL}$ microtubes. Water was used as diluent for all except phenol, and vanillin where $20 \mathrm{mM}$ universal buffer with $\mathrm{pH} 12.4$ was used as diluent (Universal buffer is composed of $0.01 \mathrm{M}$ each of phosphoric, boric, and acetic acids adjusted to $\mathrm{pH} 12.4$ with $\mathrm{NaOH}$ ). Following vortexing and a short centrifugation (12 $\mathrm{min})$, aliquots of $250-300 \mu \mathrm{L}$ were transferred into microplate wells, and the UV-vis plate reader was used to measure optical absorbance at wavelengths previously determined to correspond to maximum absorption. The maximum absorption wavelength for each compound was determined in separate experiments by analysis of the absorption spectrum over the $240-500 \mathrm{~nm}$ range. In the case of the two aforementioned compounds the maximum absorption was found to be more concentration sensitive in the presence of the universal buffer at $\mathrm{pH}$ 12.4. In all measurements the same dilution 
factor was used for the upper and lower phases and correspondingly diluted pure phases were used as blank solutions.

For the analysis of the partitioning of proteins aliquots of $30 \mu \mathrm{L}$ from both phases were transferred and diluted with water up to $70 \mu \mathrm{L}$ into microplate wells. Then, the microplate was sealed, shortly centrifuged ( $2 \mathrm{~min}$ at $1500 \mathrm{rpm}$ ) and following the moderate shaking for $45 \mathrm{~min}$ in an incubator at $37^{\circ} \mathrm{C}, 250 \mu \mathrm{L}$ of $o$-phthaldialdehyde reagent was added. After moderate shaking for $4 \mathrm{~min}$ at room temperature, fluorescence was determined using a fluorescence plate reader with a $360 \mathrm{~nm}$ excitation filter and a $460 \mathrm{~nm}$ emission filter, with a sensitivity setting of 100-125.

The partition coefficient, $\mathrm{K}$, defined as the ratio of the sample concentration in the upper phase to the sample concentration in the lower phase was determined as the slope of the compound concentration in the upper phase plotted as a function of the concentration in the lower phase averaged over the results obtained from two to four partition experiments carried out at the specified polymer, buffer, and osmolyte composition of the system, taking into consideration the corresponding dilution factors used in the experiment. The UV absorption measured in a given phase was used as a measure of a given organic compound concentration, and fluorescence intensity was used as a measure of the protein concentration. Deviation from the average $K$-value was consistently below $3 \%$ and in most cases lower than $2 \%$.

\subsubsection{Solvatochromic studies}

All aqueous two-phase systems were prepared as described above with the total weight of $15 \mathrm{~g}$. Systems were centrifuged as described above and the phases were separated. The solvatochromic probes 4-nitroanisole, 4-nitrophenol and Reichardt's carboxylated betaine dye were used to measure the dipolarity/polarizability $\pi^{*}$, HBA basicity $\beta$, and HBD acidity $\alpha$ of the media in the separated phases of ATPS. Aqueous solutions (ca. $10 \mathrm{mM}$ ) of each solvatochromic dye were prepared, and aliquots of 5-15 $\mu \mathrm{L}$ of each dye were added separately to a total volume of $500 \mu \mathrm{L}$ of a given phase of each ATPS. A strong base was added to the samples ( $\sim 5 \mu \mathrm{L}$ of $1 \mathrm{M} \mathrm{NaOH}$ to $500 \mu \mathrm{L}$ of a given phase) containing Reichardt's carboxylated betaine dye to ensure a basic $\mathrm{pH}$. A strong acid ( $\sim 10 \mu \mathrm{L}$ of $1 \mathrm{M} \mathrm{HCl}$ to $500 \mu \mathrm{L}$ of the solution) was added to the phase containing 4-nitrophenol in order to eliminate charge-transfer bands of the phenolate anion that were observed in some solutions. The samples were mixed thoroughly in a vortex mixer and the absorption spectra of each solution were acquired. To check the reproducibility, possible aggregation and specific interactions effects, the position of the band maximum in each sample was measured in six separate aliquots. A UV-vis microplate reader spectrophotometer SpectraMax Plus384 (Molecular Devices, Sunnyvale, CA, USA) with a bandwidth of $2.0 \mathrm{~nm}$, data interval of $1 \mathrm{~nm}$, and high resolution scan $(\sim 0.5 \mathrm{~nm} / \mathrm{s})$ was used for acquisition of the UV-vis molecular absorbance data. The absorption spectra of the probes were determined over the spectral range from 240 to $600 \mathrm{~nm}$ in each solution. Pure osmolyte solutions or phase of ATPS containing no dye (blank) were scanned first to establish a baseline. The wavelength of maximum absorbance in each solution was determined as described by Huddleston et al. [21] using PeakFit software package (Systat Software Inc., San Jose, CA, USA) and averaged. Standard deviation for the measured maximum absorption wavelength was $\leq 0.4 \mathrm{~nm}$ for all dyes in all solutions examined.

The behavior of the probes (4-nitrophenol, and Reichardt's carboxylated betaine dye) in several solvents (water, n-hexane, methanol) was tested in the presence and absence of $\mathrm{HCl}$ (for 4-nitrophenol) and $\mathrm{NaOH}$ (for the betaine dye) at different concentrations of the probes, acid or base, and the maximum shifts of the probes were compared to reference values found in the literature and were within the experimental errors in all cases (data not shown).
The results of the solvatochromic studies were used to calculate $\pi^{*}, \alpha$, and $\beta$ as described by Marcus [22].

2.2.3.1. Determination of the solvent dipolarity/polarizability $\pi^{*}$. The $\pi^{*}$ values were determined from the wave number $\left(v_{1}\right)$ of the longest wavelength absorption band of the 4-nitroanisole dye using the relationship:

$\pi *=0.427\left(34.12-v_{1}\right)$

2.2.3.2. Determination of the solvent hydrogen-bond acceptor basicity $\beta$. The $\beta$ values were determined from the wave number $\left(v_{2}\right)$ of the longest wavelength absorption band of the 4-nitrophenol dye using the relationship:

$\beta=0.346\left(35.045-v_{2}\right)-0.57 \pi *$

2.2.3.3. Determination of the solvent hydrogen-bond donor acidity $\alpha$. The $\alpha$ values were determined from the longest wavelength absorption band of Reichardt's betaine dye using the relationship:

$\alpha=0.0649 \mathrm{E}_{T}(30)-2.03-0.72 \pi *$

The $E_{T}(30)$ values are based on the solvatochromic pyridinium $\mathrm{N}$-phenolate betaine dye (Reichardt's dye) as probe, and are obtained directly from the wavelength $(\lambda, \mathrm{nm})$ of the absorption band of the carboxylated form, as.

$\mathrm{E}_{T}(30)=\left(\frac{1}{0.932}\right) \times\left[\left(\frac{28,591}{\lambda}\right)-3.335\right]$

\section{Results}

Differences between the solvent properties of the coexisting phases (solvent dipolarity/polarizability, $\Delta \pi^{*}$, hydrogen bond donor acidity, $\Delta \alpha$, and hydrogen bond acceptor basicity, $\Delta \beta$ ) determined using solvatochromic dyes and calculated as the difference between the measured value of a given solvent feature in the top phase and that of the same feature in the bottom phase are presented in Table 1 . The difference between the solvent hydrogen bond acidity, $\Delta \alpha$, in the PEG-8000- $\mathrm{Na}_{2} \mathrm{SO}_{4}$ ATPS in the presence of $0.215 \mathrm{M} \mathrm{NaCl}$ increases significantly, while the differences between the solvent dipolarity/polarizability, $\Delta \pi^{*}$, and hydrogen bond basicity, $\Delta \beta$, do not change within the experimental error limits. The effect of same $\mathrm{NaCl}$ additive on the differences between the solvent properties in PEG-10000- $\mathrm{Na}_{2} \mathrm{SO}_{4}$ ATPS is much more significant. Similarly the effects of the $\mathrm{NaCl}$ additive in the PEG-8000- $\mathrm{Na}_{2} \mathrm{SO}_{4}-0.5 \mathrm{M}$ osmolyte ATPSs differ depending on the particular osmolyte used. The $\mathrm{NaCl}$ additive does not affect the sequence of the differences between the solvent dipolarity/polarizability of the coexisting phases increasing as: PEG-8000- $\mathrm{Na}_{2} \mathrm{SO}_{4}-0.5 \mathrm{M}$ TMAO $<$ PEG-10000$\mathrm{Na}_{2} \mathrm{SO}_{4}<\mathrm{PEG}-8000-\mathrm{Na}_{2} \mathrm{SO}_{4}<\mathrm{PEG}-8000-\mathrm{Na}_{2} \mathrm{SO}_{4}-0.5 \mathrm{M}$ sorbitol $<$ PEG-8000- $\mathrm{Na}_{2} \mathrm{SO}_{4}-0.5 \mathrm{M}$ sucrose. The differences between the hydrogen bond donor acidity of the two phases are affected by the $\mathrm{NaCl}$ additive noticeably: the sequence changes from PEG$10000-\mathrm{Na}_{2} \mathrm{SO}_{4}<$ PEG-8000- $\mathrm{Na}_{2} \mathrm{SO}_{4}<\mathrm{PEG}-8000-\mathrm{Na}_{2} \mathrm{SO}_{4}-0.5 \mathrm{M}$

TMAO $<$ PEG-8000- $\mathrm{Na}_{2} \mathrm{SO}_{4}-0.5 \mathrm{M}$ sorbitol $<$ PEG-8000- $\mathrm{Na}_{2} \mathrm{SO}_{4}-$ $0.5 \mathrm{M}$ sucrose to: PEG-10000- $\mathrm{Na}_{2} \mathrm{SO}_{4}-0.215 \mathrm{M} \quad \mathrm{NaCl} \leq \mathrm{PEG}-$ $8000-\mathrm{Na}_{2} \mathrm{SO}_{4}-0.215 \mathrm{M} \quad \mathrm{NaCl}<\mathrm{PEG}-8000-\mathrm{Na}_{2} \mathrm{SO}_{4}-0.215 \mathrm{M} \mathrm{NaCl}-$ $0.5 \mathrm{M}$ sucrose $\leq \mathrm{PEG}-8000-\mathrm{Na}_{2} \mathrm{SO}_{4}-0.215 \mathrm{M}$ NaCl-0.5 M sorbitol $<$ PEG-8000-Na $\mathrm{SO}_{4}-0.215 \mathrm{M} \mathrm{NaCl}-0.5 \mathrm{M}$ TMAO. The effect of the $\mathrm{NaCl}$ additive on the differences between the solvent hydrogen bond basicity of the phases barely exceeds the experimental error limits.

The differences between the hydrophobic and electrostatic properties of the phases were determined in each ATPS by partitioning of a homologous series of sodium salts of dinitrophenylated 
Table 1

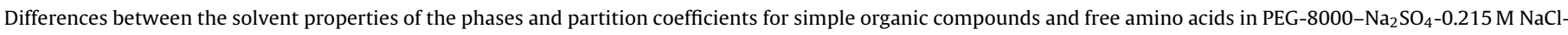

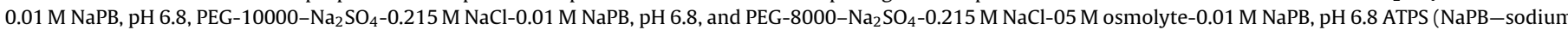
phosphate buffer).

\begin{tabular}{|c|c|c|c|c|c|}
\hline Solvent properties ${ }^{\mathrm{c}}$ & $0.01 \mathrm{M} \mathrm{NaPB}^{\mathrm{a}}$ & $0.01 \mathrm{M} \mathrm{NaPB}^{\mathrm{b}}$ & 0.5M Sorbitol & 0.5M Sucrose & 0.5M TMAO \\
\hline$\Delta G\left(\mathrm{CH}_{2}\right)(\mathrm{cal} / \mathrm{mol})$ & $-135 \pm 10.6$ & $-147 \pm 6.5$ & $-180 \pm 5.3$ & $-187 \pm 2.9$ & $-160 \pm 2.4$ \\
\hline E & $0.102 \pm 0.008$ & $0.110 \pm 0.005$ & $0.133 \pm 0.004$ & $0.138 \pm 0.002$ & $0.118 \pm 0.002$ \\
\hline C & $0.49 \pm 0.031$ & $0.44 \pm 0.019$ & $0.53 \pm 0.015$ & $0.525 \pm 0.008$ & $0.574 \pm 0.006$ \\
\hline$\Delta \pi^{*}$ & $-0.027 \pm 0.003$ & $-0.039 \pm 0.002$ & $-0.056 \pm \pm 0.001$ & $-0.067 \pm 0.001$ & $-0.025 \pm 0.004$ \\
\hline$\Delta \alpha$ & $-0.189 \pm 0.004$ & $-0.183 \pm 0.004$ & $-0.259 \pm 0.003$ & $-0.253 \pm 0.003$ & $-0.271 \pm 0.004$ \\
\hline$\Delta \beta$ & $0.013 \pm 0.004$ & $0.021 \pm 0.003$ & $0.025 \pm 0.002$ & $0.022 \pm 0.002$ & $0.015 \pm 0.005$ \\
\hline Compound & \multicolumn{5}{|c|}{ Partition coefficients } \\
\hline Benzyl alcohol & $4.067 \pm 0.008$ & $4.146 \pm 0.007$ & $6.08 \pm 0.018$ & $6.61 \pm 0.038$ & $4.71 \pm 0.016$ \\
\hline Caffeine & $2.11 \pm 0.036$ & $2.356 \pm 0.006$ & $2.720 \pm 0.008$ & $2.550 \pm 0.007$ & $2.819 \pm 0.008$ \\
\hline Coumarin & $4.86 \pm 0.014$ & $4.55 \pm 0.023$ & $8.23 \pm 0.024$ & $8.46 \pm 0.065$ & $6.27 \pm 0.024$ \\
\hline Glucopyranoside $^{\mathrm{d}}$ & $2.47 \pm 0.033$ & $2.916 \pm 0.003$ & $3.957 \pm 0.001$ & $4.05 \pm 0.01$ & $3.41 \pm 0.011$ \\
\hline Methyl anthranilate & $9.59 \pm 0.027$ & $9.58 \pm 0.023$ & $14.8 \pm 0.29$ & $16.42 \pm 0.048$ & $11.77 \pm 0.082$ \\
\hline Phenol & $6.5 \pm 0.17$ & $6.54 \pm 0.018$ & $10.60 \pm 0.03$ & $11.97 \pm 0.055$ & $7.38 \pm 0.022$ \\
\hline 2-Phenylethanol & $4.98 \pm 0.012$ & $5.05 \pm 0.013$ & $7.39 \pm 0.023$ & $8.52 \pm 0.025$ & $5.60 \pm 0.025$ \\
\hline Vanillin & $8.28 \pm 0.020$ & $8.31 \pm 0.017$ & $13.03 \pm 0.04$ & $13.22 \pm 0.044$ & $7.58 \pm 0.029$ \\
\hline DNP-Ala Na & $4.43 \pm 0.12$ & $3.99 \pm 0.015$ & $5.12 \pm 0.010$ & $5.09 \pm 0.018$ & $5.40 \pm 0.02$ \\
\hline DNP-NVal Na & $5.43 \pm 0.099$ & $5.36 \pm 0.012$ & $7.68 \pm 0.031$ & $7.87 \pm 0.021$ & $7.60 \pm 0.018$ \\
\hline DNP-NLeu Na & $7.15 \pm 0.032$ & $6.88 \pm 0.027$ & $10.23 \pm 0.036$ & $10.81 \pm 0.048$ & $10.49 \pm 0.016$ \\
\hline DNP-AO Na & $13.93 \pm 0.23$ & $14.01 \pm 0.035$ & $23.6 \pm 0.13$ & $25.04 \pm 0.11$ & $20.88 \pm 0.08$ \\
\hline
\end{tabular}

a Data for osmolyte-free PEG-8000- $\mathrm{Na}_{2} \mathrm{SO}_{4}-0.215 \mathrm{M} \mathrm{NaCl}-0.01 \mathrm{M}$ NaPB, pH 6.8 ATPS.

b Data for osmolyte-free PEG-10000- $\mathrm{Na}_{2} \mathrm{SO}_{4}-0.215 \mathrm{M} \mathrm{NaCl}-0.01 \mathrm{M} \mathrm{NaPB}, \mathrm{pH} 6.8$ ATPS.

c Parameters $E$ and $\Delta G\left(\mathrm{CH}_{2}\right)$ values characterize the difference between the relative hydrophobicities of the coexisting phases of a given ATPS, parameter $C$ value character-

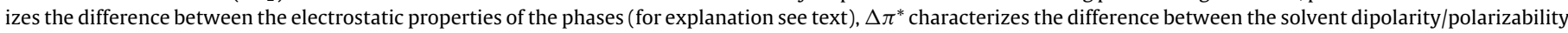

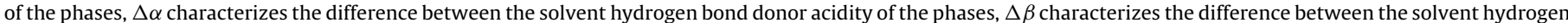
bond acceptor basicity of the phases.

d $p$-Nitrophenyl- $\alpha$-D-glucopyranoside.

e DNP-amino- $n$-octanoic acid sodium salt.

(DNP-) amino acids with the aliphatic alkyl side-chains of the increasing length (alanine, norvaline, norleucine, and $\alpha$-amino- $n$ octanoic acid) as described previously [19,20]. Partition coefficients of these compounds are listed in Table 1.

Differences between the solvent properties of the two phases in each ATPS used are presented in Table 1 together with partition coefficients for eight organic compounds examined here.

Partitioning of six proteins was examined in all the aforementioned ATPSs and the corresponding partition coefficients are listed in Table 2.

\section{Discussion}

\subsection{Effect of NaCl additive on solvent properties of PEG-sodium sulfate ATPS}

The solvent properties of each ATPS are represented by the set of differences between the solvent features of the coexisting phases: $\Delta \pi^{*}, \Delta \alpha, \Delta \beta, C$, and $E$ values, listed in Table 1 . The set of the $\Delta \pi^{*}$, $\Delta \alpha, \Delta \beta, C$, and $E$ values for a given ATPS may be viewed as a point in a multiple dimensional space of solvent properties. To compare the properties of different ATPSs we calculated the normalized Euclidian distance in the multi-dimensional space represented by the differences between the solvent features of the coexisting phases in different ATPSs:

$d_{i, o}=\left[\sum_{j}\left(\frac{\partial_{i}-\partial_{o}}{\partial_{o}}\right)^{2}\right]^{0.5}$

where $d_{i, o}$ is the distance between the solvent properties of $i$ th ATPS and solvent properties of the oth ATPS chosen as a reference, $\partial_{i}$ and $\partial_{o}$ are the differences between the $j$ th solvent features in $i$ th and oth ATPSs.

To compensate for differences in $\partial$-values measured for a given solvent property in different ATPSs, we normalized the experimental $\partial$-values to the reference $\partial_{o}$-value for each particular solvent property. Therefore, Eq. (6) represents the Euclidean distance between the points represented by normalized differences between various solvent features in different ATPSs.

In order to evaluate the effect of the $\mathrm{NaCl}$ additive on the properties of the ATPSs used here and previously [19] we selected PEG-8000- $\mathrm{Na}_{2} \mathrm{SO}_{4}$ ATPS as a reference ATPS. The normalized Euclidean distances calculated with Eq. (6) are listed in Table 3. The data in Table 3 indicate that the effect of $0.215 \mathrm{M} \mathrm{NaCl}$ on the overall solvent properties of the PEG-8000- $\mathrm{Na}_{2} \mathrm{SO}_{4}$ ATPS is rather

Table 2

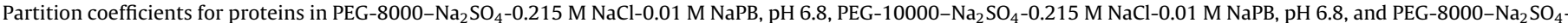
$0.215 \mathrm{M} \mathrm{NaCl}-0.5 \mathrm{M}$ osmolyte-0.01 M NaPB, pH 6.8 ATPS (NaPB - sodium phosphate buffer).

\begin{tabular}{|c|c|c|c|c|c|}
\hline \multirow[b]{2}{*}{ Protein } & \multicolumn{5}{|c|}{ Partition coefficients } \\
\hline & $0.01 \mathrm{M} \mathrm{NaPB}^{\mathrm{a}}$ & $0.01 \mathrm{M} \mathrm{NaPB}^{\mathrm{b}}$ & $0.5 \mathrm{M} \mathrm{Sorbitol}^{\mathrm{c}}$ & $0.5 \mathrm{M}$ Sucrose & $0.5 \mathrm{M}$ TMAO \\
\hline$\alpha$-Chymotrypsinogen & $0.543 \pm 0.003$ & $0.472 \pm 0.002$ & $0.335 \pm 0.001$ & $0.365 \pm 0.001$ & $0.601 \pm 0.002$ \\
\hline Chymotrypsin & $0.110 \pm 0.001$ & $0.0814 \pm 0.0004$ & $0.0412 \pm 0.0004$ & $0.043 \pm 0.0005$ & $0.0816 \pm 0.0006$ \\
\hline Concanavalin A & $0.183 \pm 0.001$ & $0.173 \pm 0.003$ & $0.146 \pm 0.001$ & $0.130 \pm 0.001$ & $0.167 \pm 0.001$ \\
\hline Lipase & $0.584 \pm 0.001$ & $0.585 \pm 0.002$ & $0.534 \pm 0.002$ & $0.522 \pm 0.003$ & $0.538 \pm 0.003$ \\
\hline Lysozyme & $0.983 \pm 0.003$ & $0.929 \pm 0.003$ & $0.561 \pm 0.002$ & $0.335 \pm 0.002$ & $0.786 \pm 0.003$ \\
\hline Papain & $1.92 \pm 0.007$ & $1.67 \pm 0.010$ & $2.06 \pm 0.015$ & $1.625 \pm 0.005$ & $2.23 \pm 0.010$ \\
\hline
\end{tabular}

a Data for osmolyte-free PEG-8000- $\mathrm{Na}_{2} \mathrm{SO}_{4}-0.215 \mathrm{M} \mathrm{NaCl}-0.01 \mathrm{M}$ NaPB, pH 6.8 ATPS.

b Data for osmolyte-free PEG-10000- $\mathrm{Na}_{2} \mathrm{SO}_{4}-0.215 \mathrm{M} \mathrm{NaCl}-0.01 \mathrm{M} \mathrm{NaPB}, \mathrm{pH} 6.8$ ATPS

c Data for PEG-8000- $\mathrm{Na}_{2} \mathrm{SO}_{4}-0.215 \mathrm{M} \mathrm{NaCl}-0.5 \mathrm{M}$ osmolyte-0.01 M NaPB, pH 6.8 ATPS. 
Table 3

Normalized Euclidean distances between the solvent properties of ATPSs indicated and those of PEG-8000- $\mathrm{Na}_{2} \mathrm{SO}_{4}$ calculated with Eq. (6) from the data in Table 1 and data in [19].

\begin{tabular}{ll}
\hline ATPS $^{*}$ & Distance, $d_{i, o}$ \\
\hline PEG-8000- $\mathrm{Na}_{2} \mathrm{SO}_{4}$ & 0 \\
PEG-10000- $\mathrm{Na}_{2} \mathrm{SO}_{4}$ & $1.21 \pm 0.05$ \\
PEG-8000- $\mathrm{Na}_{2} \mathrm{SO}_{4}-0.215 \mathrm{M} \mathrm{NaCl}$ & $1.24 \pm 0.05$ \\
PEG-10000- $\mathrm{Na}_{2} \mathrm{SO}_{4}-0.215 \mathrm{M} \mathrm{NaCl}$ & $1.46 \pm 0.06$ \\
PEG-8000- $\mathrm{Na}_{2} \mathrm{SO}_{4}-0.5 \mathrm{M}$ TMAO & $1.64 \pm 0.06$ \\
PEG-8000- $\mathrm{Na}_{2} \mathrm{SO}_{4}-0.5 \mathrm{M}$ sorbitol & $1.70 \pm 0.05$ \\
PEG-8000- $\mathrm{Na}_{2} \mathrm{SO}_{4}-0.215 \mathrm{M} \mathrm{NaCl}-0.5 \mathrm{M}$ TMAO & $1.86 \pm 0.06$ \\
PEG-8000- $\mathrm{Na}_{2} \mathrm{SO}_{4}-0.215 \mathrm{M} \mathrm{NaCl}-0.5 \mathrm{M}$ sorbitol & $2.35 \pm 0.05$ \\
PEG-8000- $\mathrm{Na}_{2} \mathrm{SO}_{4}-0.5 \mathrm{M}$ trehalose & $2.39 \pm 0.06$ \\
PEG-8000- $\mathrm{Na}_{2} \mathrm{SO}_{4}-0.215 \mathrm{M}$ NaCl-0.5 M sucrose & $2.54 \pm 0.05$ \\
PEG-8000- $\mathrm{Na}_{2} \mathrm{SO}_{4}-0.5 \mathrm{M}$ sucrose & $2.61 \pm 0.05$ \\
\hline
\end{tabular}

${ }^{*}$ Each ATPS contains 11.10 wt.\% PEG-8000, 6.33 wt.\% $\mathrm{Na}_{2} \mathrm{SO}_{4}$, and 0.01 M NaPB pH 6.8 (NaPB-sodium phosphate buffer).

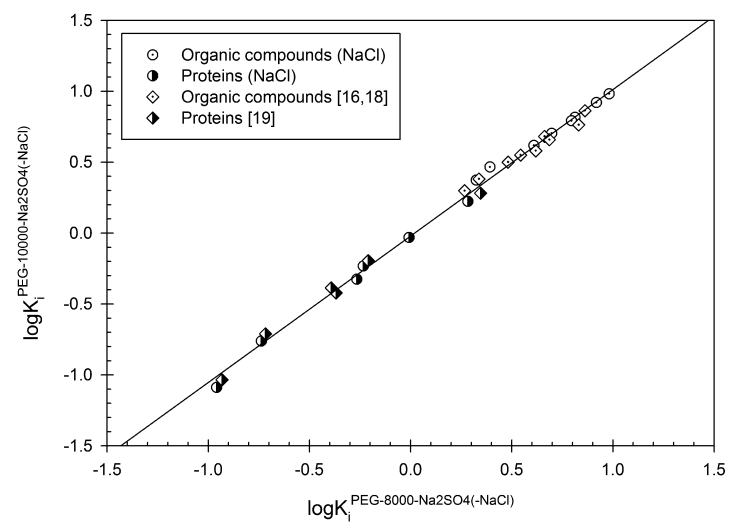

Fig. 1. Logarithms of partition coefficients for organic compounds and proteins in PEG-10000- $\mathrm{Na}_{2} \mathrm{SO}_{4}-0.01 \mathrm{M}$ sodium phosphate buffer (NaPB), pH 6.8 with and without $0.215 \mathrm{M} \mathrm{NaCl}$ additive ATPSs versus those for the same compounds and proteins in PEG-8000- $\mathrm{Na}_{2} \mathrm{SO}_{4}-0.01 \mathrm{M}$ sodium phosphate buffer ( $\mathrm{NaPB}$ ), $\mathrm{pH} 6.8$ with and without $0.215 \mathrm{M} \mathrm{NaCl}$ additive ATPSs.

small in osmolyte-free ATPS, depends on the presence of particular osmolyte, and increases in the sequence: TMAO < sorbitol < sucrose.

Analysis of partition coefficients determined in this study for various organic compounds and proteins listed in Tables 1 and 2 shows that the so-called Collander solvent regression equation (see, e.g., in [18-20]) holds for all compounds (including proteins) in the PEG-8000- $\mathrm{Na}_{2} \mathrm{SO}_{4}-0.215 \mathrm{M} \mathrm{NaCl}$ and PEG-10000- $\mathrm{Na}_{2} \mathrm{SO}_{4}-$ $0.215 \mathrm{M} \mathrm{NaCl}$ ATPSs and the same NaCl-free ATPSs [19] as shown in Fig. 1. The linear relationship plotted in Fig. 1 may be described as:

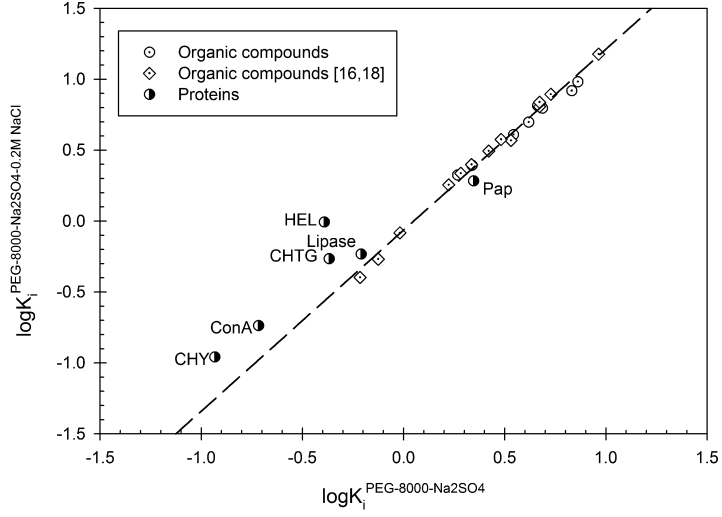

Fig. 2. Logarithms of partition coefficients for organic compounds and proteins in PEG-8000- $\mathrm{Na}_{2} \mathrm{SO}_{4}-0.215 \mathrm{M} \mathrm{NaCl}-0.01 \mathrm{M}$ sodium phosphate buffer (NaPB), pH 6.8 ATPS versus those for the same compounds and proteins in PEG-8000- $\mathrm{Na}_{2} \mathrm{SO}_{4}$ $0.01 \mathrm{M}$ sodium phosphate buffer (NaPB), pH 6.8 ATPS (line described the linear relationship observed for organic compounds).

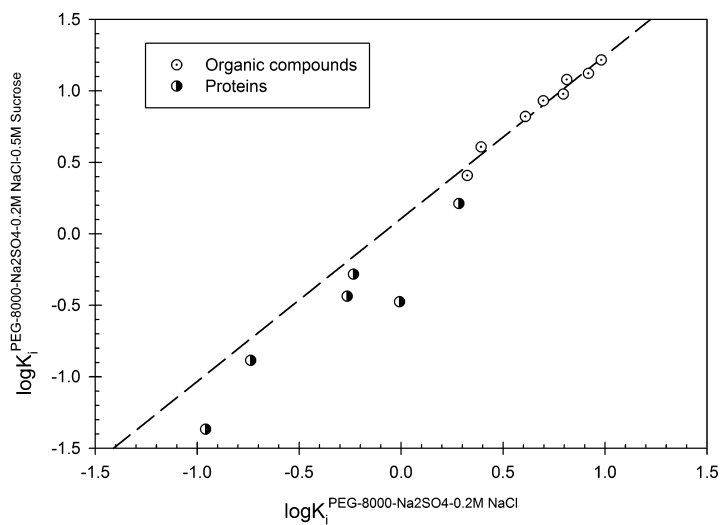

Fig. 3. Logarithms of partition coefficients for organic compounds and proteins in PEG-8000-Na $\mathrm{SO}_{4}-0.5 \mathrm{M}$ sucrose- $0.215 \mathrm{M} \mathrm{NaCl}-0.01 \mathrm{M}$ sodium phosphate buffer (NaPB), pH 6.8 ATPS versus those for the same compounds and proteins in PEG$8000-\mathrm{Na}_{2} \mathrm{SO}_{4}-0.215 \mathrm{M} \mathrm{NaCl}-0.01 \mathrm{M}$ sodium phosphate buffer (NaPB), pH 6.8 ATPS (line described the linear relationship observed for organic compounds).

same compounds in the $\mathrm{NaCl}$ free PEG-8000- $\mathrm{Na}_{2} \mathrm{SO}_{4}$ ATPS reported previously $[16,18,19]$, illustrated graphically in Fig. 2 shows that the Collander solvent regression relationship holds for organic compounds but not for proteins. The relationship in Fig. 2 may be described as:

$$
\begin{gathered}
\log K_{i}^{\mathrm{PEG}-8000-\mathrm{Na}_{2} \mathrm{SO}_{4}-0.215 \mathrm{MNaCl}}=-0.08_{ \pm 0.013}+1.33_{ \pm 0.026} \times \log K_{i}^{\mathrm{PEG}-8000-\mathrm{Na}_{2} \mathrm{SO}_{4}} \\
N=13 ; \quad r^{2}=0.9958 ; \quad \mathrm{SD}=0.032 ; \quad F=2583
\end{gathered}
$$

$$
\begin{gathered}
\log K_{i}^{\mathrm{PEG}-10000-\mathrm{Na}_{2} \mathrm{SO}_{4}(0.215 \mathrm{M} \mathrm{NaCl})}=-0.02_{ \pm 0.01}+1.03_{ \pm 0.01} \times \log K_{i}^{\mathrm{PEG}-8000-\mathrm{Na}_{2} \mathrm{SO}_{4}(0.215 \mathrm{M} \mathrm{NaCl})} \\
N=29 ; \quad r^{2}=0.9955 ; \quad \mathrm{SD}=0.042 ; \quad F=5953
\end{gathered}
$$

where

$K^{\mathrm{PEG}-10000-\mathrm{Na}_{2} \mathrm{SO}_{4}(0.215 \mathrm{M} \mathrm{NaCl})}$

and $K_{i}^{\mathrm{PEG}-10000-\mathrm{Na}_{2} \mathrm{SO}_{4}(0.215 \mathrm{MNaCl})}$ are partition coefficients for the $i$ th compound in PEG-8000- $\mathrm{Na}_{2} \mathrm{SO}_{4}$ and PEG-10000- $\mathrm{Na}_{2} \mathrm{SO}_{4}$ with and without $0.215 \mathrm{M} \mathrm{NaCl}$ ATPSs correspondingly; $N$-number of compounds; $r^{2}$-correlation coefficient; SD-standard deviation; $F$-ratio of variance.

Comparison of the partition coefficients of organic compounds and proteins in PEG-8000- $\mathrm{Na}_{2} \mathrm{SO}_{4}-\mathrm{NaCl}$ ATPS with those for the where all the parameters are as defined above. The proteins examined do not fit the relationship likely due to the different protein-specific responses to the presence of $\mathrm{NaCl}$ additive.

Analysis of the data in Tables 1 and 2 shows that the $\mathrm{NaCl}$ additive affects partition behavior of proteins to a much more significant degree than that of organic compounds as may be illustrated by Fig. 3 where logarithms of partition coefficients of organic compounds and proteins in the PEG-8000- $\mathrm{Na}_{2} \mathrm{SO}_{4}-0.5 \mathrm{M}$ 
sucrose- $0.215 \mathrm{M} \mathrm{NaCl}$ ATPS are plotted versus those in the same $\mathrm{NaCl}$ additive free ATPS. Partition coefficients of lysozyme, $\alpha$ chymotrypsinogen (CHTG), and papain clearly do not fit the linear curve representing the Collander solvent regression relationship observed for organic compounds. It should be mentioned that the relationship observed is essentially identical to the one reported [19] previously in the same but $\mathrm{NaCl}$-free ATPSs.

Similar relationship for the $\mathrm{PEG}-\mathrm{Na}_{2} \mathrm{SO}_{4}-\mathrm{TMAO}-\mathrm{NaCl}$, PEG- $\mathrm{Na}_{2} \mathrm{SO}_{4}$-sorbitol- $\mathrm{NaCl}$, and PEG- $\mathrm{Na}_{2} \mathrm{SO}_{4}$-sucrose- $\mathrm{NaCl}$ ATPSs is illustrated graphically in Fig. 5 and may be described as: $\log K_{i}^{\mathrm{PEG}-8000-\mathrm{Na}_{2} \mathrm{SO}_{4}-\text { sorbitol-NaCl }}=-0.01_{ \pm 0.02}+0.5_{ \pm 0.16} \times \log K_{i}^{\mathrm{PEG}-8000-\mathrm{Na}_{2} \mathrm{SO}_{4}-\mathrm{TMAO}-\mathrm{NaCl}}+0.6_{ \pm 0.13} \times \log K_{i}^{\mathrm{PEG}^{\mathrm{PE}}-8000-\mathrm{Na}_{2} \mathrm{SO}_{4}-\mathrm{sucrose}}$

$$
N=14 ; \quad r^{2}=0.9961 ; \quad S D=0.054 ; \quad F=1418
$$

partition coefficients of some of the proteins, such as lipase, concanavalin $\mathrm{A}$, and $\alpha$-chymotrypsin, are very close to the relationship in question. Similar pattern is observed for the ATPS with $0.5 \mathrm{M}$ TMAO and $0.5 \mathrm{M}$ sorbitol. where all the parameters are as defined above.

It should be noted that the similar relationships are observed if the logarithms of partition coefficients in NaCl-free ATPS [19] is compared with those in ATPSs with $\mathrm{NaCl}$ additive. Typical relationship is illustrated graphically in Fig. 6 and it may be described as:

$$
N=14 ; \quad r^{2}=0.9922 ; \quad \mathrm{SD}=0.065 ; \quad F=697
$$

It has been shown [19] previously that logarithms of partition coefficients of proteins and organic compounds in PEG- $\mathrm{Na}_{2} \mathrm{SO}_{4}$ $0.5 \mathrm{M}$ osmolyte, all containing $0.01 \mathrm{M}$ sodium/potassium phosphate buffer, pH 6.8 are linearly interrelated in a three dimensional space. Analysis of the partition coefficients listed in Tables 1 and 2 show that similar relationships exists for all compounds examined in PEG- $\mathrm{Na}_{2} \mathrm{SO}_{4}-0.5 \mathrm{M}$ osmolyte- $0.215 \mathrm{M} \mathrm{NaCl}$ ATPS as well. The relationship illustrated graphically in Fig. 4 is observed between logarithms of partition coefficients of compounds (including proteins) in PEG- $\mathrm{Na}_{2} \mathrm{SO}_{4}-0.215 \mathrm{M} \mathrm{NaCl}$, PEG- $\mathrm{Na}_{2} \mathrm{SO}_{4}-0.5 \mathrm{M}$ sucrose- $0.215 \mathrm{M} \mathrm{NaCl}$, and $\mathrm{PEG}-\mathrm{Na}_{2} \mathrm{SO}_{4}-0.5 \mathrm{M}$ sorbitol- $0.215 \mathrm{M}$ $\mathrm{NaCl}$ and it may be described as: where all the parameters are as defined above.

It was suggested previously [23] that the relationships of the type represented by Eqs. (7)-(11) imply that the compounds respond to their environment in aqueous solutions in the compound structure- and environment-specific manner, and also that the responses are governed by changes in the compound-water interactions possibly originating from the compound dipole-ion interactions.

$$
N=14 ; \quad r^{2}=0.9956 ; \quad \mathrm{SD}=0.051 ; \quad F=1628
$$

where $-\mathrm{NaCl}$ superscript denoted that the logarithms of partition coefficients in the ATPS with $0.215 \mathrm{M} \mathrm{NaCl}$ additive were used; all the parameters are as defined above. It should be mentioned that

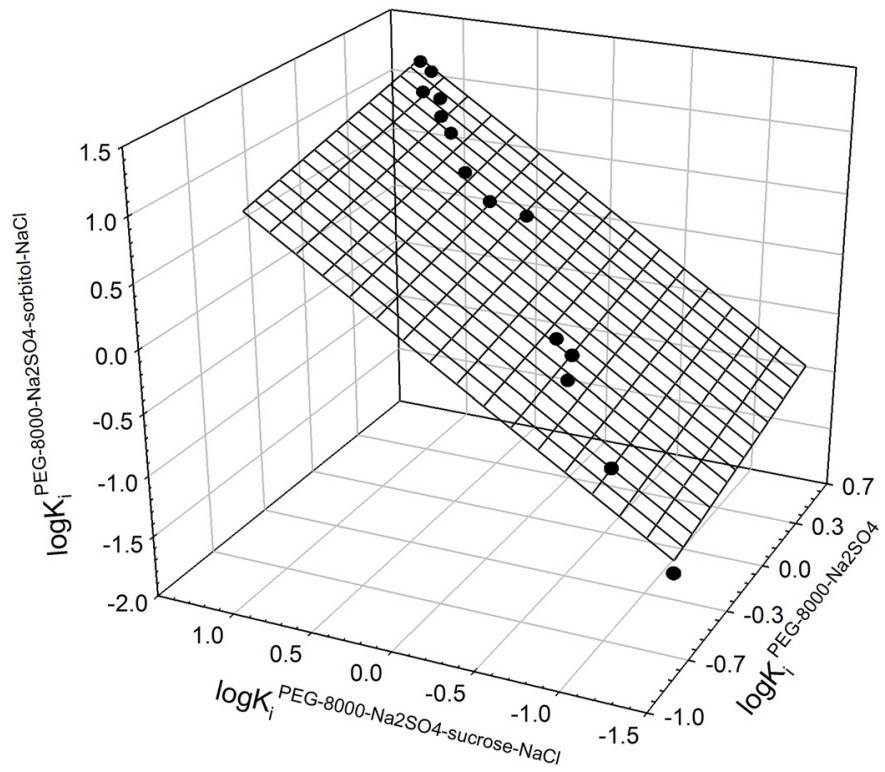

Fig. 4. Logarithms of partition coefficients for organic compounds and proteins in PEG-8000- $\mathrm{Na}_{2} \mathrm{SO}_{4}-0.5 \mathrm{M}$ sorbitol-0.215 M NaCl-0.01 M sodium phosphate buffer (NaPB), pH 6.8 ATPS versus those for the same compounds and proteins in PEG-8000- $\mathrm{Na}_{2} \mathrm{SO}_{4}-0.01 \mathrm{M}$ sodium phosphate buffer (NaPB), pH 6.8 ATPS and in PEG$8000-\mathrm{Na}_{2} \mathrm{SO}_{4}-0.5 \mathrm{M}$ sucrose- $0.215 \mathrm{M} \mathrm{NaCl}-0.01 \mathrm{M}$ sodium phosphate buffer (NaPB), pH 6.8 ATPS.

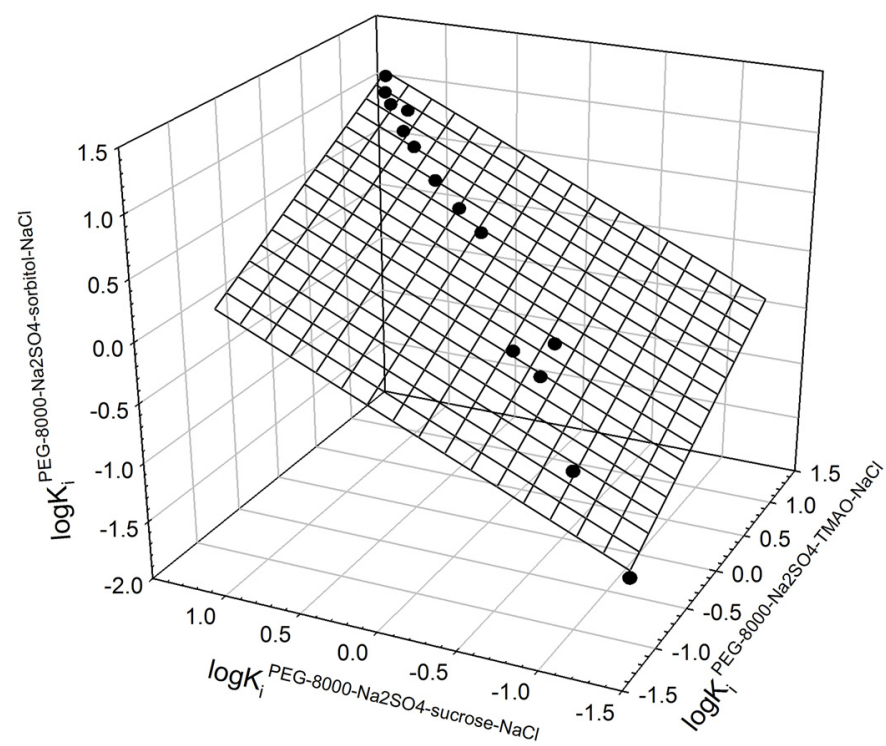

Fig. 5. Logarithms of partition coefficients for organic compounds and proteins in PEG-8000- $\mathrm{Na}_{2} \mathrm{SO}_{4}-0.5 \mathrm{M}$ sorbitol-0.215 M NaCl-0.01 M sodium phosphate buffer (NaPB), pH 6.8 ATPS versus those for the same compounds and proteins in PEG$8000-\mathrm{Na}_{2} \mathrm{SO}_{4}-0.5 \mathrm{M}$ TMAO- $0.215 \mathrm{M} \mathrm{NaCl}-0.01 \mathrm{M}$ sodium phosphate buffer (NaPB), pH 6.8 ATPS and in PEG-8000- $\mathrm{Na}_{2} \mathrm{SO}_{4}-0.5 \mathrm{M}$ sucrose-0.215 M NaCl-0.01 M sodium phosphate buffer (NaPB), pH 6.8 ATPS. 


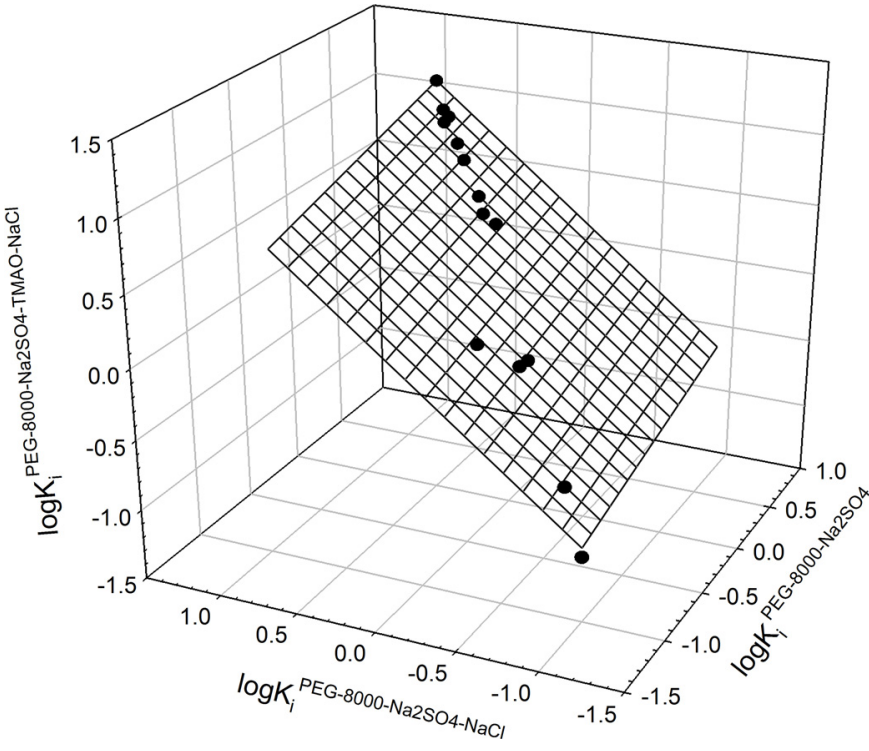

Fig. 6. Logarithms of partition coefficients for organic compounds and proteins in PEG-8000- $\mathrm{Na}_{2} \mathrm{SO}_{4}-0.5 \mathrm{M}$ TMAO-0.215 M NaCl-0.01 M sodium phosphate buffer (NaPB), pH 6.8 ATPS versus those for the same compounds and proteins in PEG-8000- $\mathrm{Na}_{2} \mathrm{SO}_{4}-0.01 \mathrm{M}$ sodium phosphate buffer (NaPB), pH 6.8 ATPS and in PEG-8000- $\mathrm{Na}_{2} \mathrm{SO}_{4}-0.215 \mathrm{M} \mathrm{NaCl}-0.01 \mathrm{M}$ sodium phosphate buffer (NaPB), pH 6.8 ATPS.

\subsection{Organic compound-water interactions in PEG-sodium sulfate ATPS}

The partition coefficients for organic compounds listed in Table 1 were examined with Eq. 1 . The solute-specific coefficients were determined by multiple linear regression analysis using the procedure described by Ab Rani et al. [24]. According to this procedure [24], the $p$-value was used for a given compound as a test for significance for each solute-specific coefficient in Eq. (1). In view of the small number of five ATPSs employed (and additional condition of partition coefficient $K$-value $=1$ for the compound in the theoretical critical point in an ATPS, when both phases have identical composition; i.e., no difference between each of the solvent properties of the phases [20]), we have used the maximum statistical significance value of $p \leq 0.1$. If all four coefficients $\left(S_{S}\right.$, $A_{s}, B_{s}$, and $C_{s}$ ) proved statistically significant $(p \leq 0.1)$, the correlation was accepted. If one or more values reveal a $p$-value $>0.1$, then equations contained different combinations of coefficients were examined. The equation with a set of coefficients providing $p$-values for all parameters below or equal to 0.1 was accepted.

The solute-specific coefficients determined for each compound and those for the same compounds determined in the absence of $\mathrm{NaCl}$ additive [19] are presented in Table 4 with the corresponding $p$-values (except the cases when $p<0.001$ ) and the solute-specific coefficients.

Comparison of the solute-specific coefficients $S_{S}$ representing the contribution of dipole-dipole solute-solvent interactions into partition coefficients of the compounds in PEG- $\mathrm{Na}_{2} \mathrm{SO}_{4}$ ATPS in the absence and in the presence of $0.215 \mathrm{M} \mathrm{NaCl}$ indicate that there is a linear relationship illustrated graphically in Fig. 7 that may be described as:

$$
\begin{gathered}
S_{S}^{\mathrm{iPEG}-\mathrm{Na}_{2} \mathrm{SO}_{4}-0.215 \mathrm{M} \mathrm{NaCl}}=0.7_{ \pm 0.3}+1.9_{ \pm 0.13} \times S_{S}^{\mathrm{i} \mathrm{PEG}-\mathrm{Na}_{2} \mathrm{SO}_{4}} \\
N=7 ; \quad r^{2}=0.9779 ; \quad \mathrm{SD}=0.35 ; \quad F=221
\end{gathered}
$$

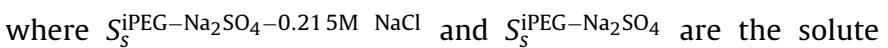
specific coefficients $S_{S}$ for $i$ th organic compound determined in

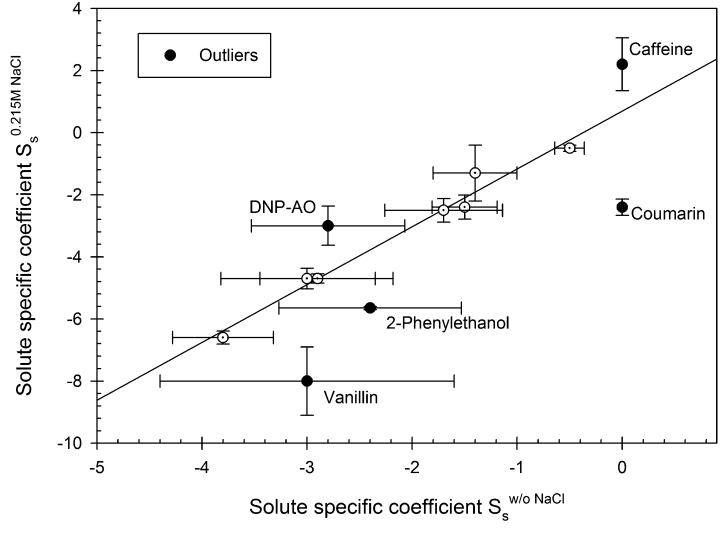

Fig. 7. Interrelationship between solute-specific coefficients $S_{S}{ }_{S}^{0.215 \mathrm{M} \mathrm{NaCl}}$ for organic compounds and solute-specific coefficients $S_{S}$ w/o NaCl for the same compounds determined in the presence and absence of $0.215 \mathrm{M} \mathrm{NaCl}$ correspondingly. The solute-specific coefficient $S_{S}$ represents the contribution of dipole-dipole and dipoleinduced dipole interactions between a given compound and aqueous media in the phases into solute partition coefficient.

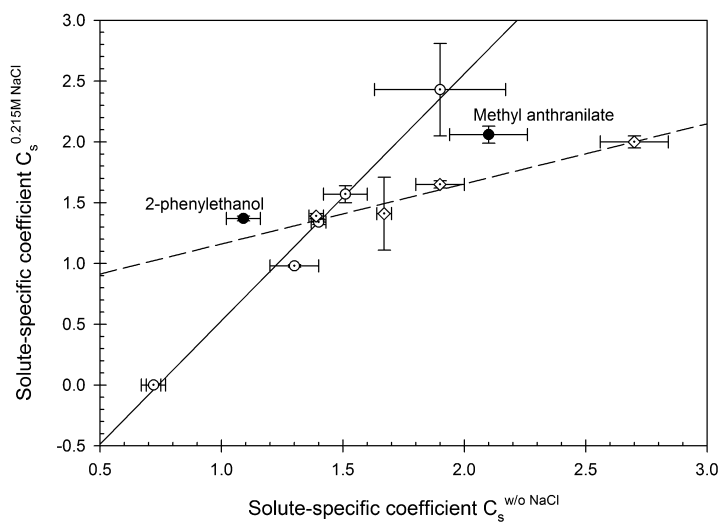

Fig. 8. Interrelationships between solute-specific coefficients $C_{S} 0.215 \mathrm{M} \mathrm{NaCl}$ for nonionic organic compounds (circles) and charged DNP-amino acids sodium salts (diamonds) and solute-specific coefficients $C_{S}$ w/o NaCl for the same compounds determined in the presence and absence of $0.215 \mathrm{M} \mathrm{NaCl}$ correspondingly. The solute-specific coefficient $C_{s}$ represents the contribution of electrostatic interactions between a given compound and aqueous media in the phases into solute partition coefficient.

PEG- $\mathrm{Na}_{2} \mathrm{SO}_{4}-0.215 \mathrm{M} \mathrm{NaCl}$ and PEG- $\mathrm{Na}_{2} \mathrm{SO}_{4}$ ATPS, correspondingly; all the other parameters are as defined above. It should be mentioned that caffeine, coumarin, 2-phenylethanol, vanillin, and DNP-amino-n-octanoic acid Na-salt were considered to be outliers and not included in the relationship. Two of these compounds (caffeine and coumarin) show $S_{s}$ value to be insignificant in the absence of $\mathrm{NaCl}$ [19], while the three other compounds might be included taking into account large experimental errors for the $S_{s}$ values. It should be noted that Eq. (12) indicates that the coefficient $S_{\mathrm{s}}$ value for nonionic compounds increases in the presence of $\mathrm{NaCl}$ likely due to ion-dipole interactions.

Comparison of the solute-specific coefficient $C_{S}$ values determined for the same compounds in the PEG- $\mathrm{Na}_{2} \mathrm{SO}_{4}$ and in PEG- $\mathrm{Na}_{2} \mathrm{SO}_{4}-0.215 \mathrm{M} \mathrm{NaCl}$ ATPSs shows that the linear relationship similar to the one discussed above is also observed. It is presented graphically in Fig. 8 and may be described as:

$$
\begin{gathered}
C_{S}^{\mathrm{iPEG}-\mathrm{Na}_{2} \mathrm{SO}_{4}-0.215 \mathrm{M} \mathrm{NaCl}}=-1.5_{ \pm 0.12}+2.0_{ \pm 0.09} \times C_{S}^{\mathrm{i} \mathrm{PEG}-\mathrm{Na}_{2} \mathrm{SO}_{4}} \\
N=6 ; \quad r^{2}=0.9925 ; \quad \mathrm{SD}=0.092 ; \quad F=528
\end{gathered}
$$


Table 4

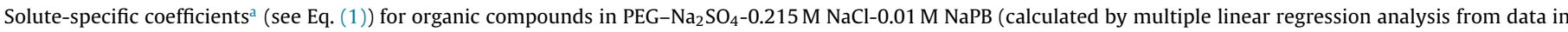
Table 1). NaPB-sodium phosphate buffer, pH 6.8 and in PEG- $\mathrm{Na}_{2} \mathrm{SO}_{4}-0.01 \mathrm{M} \mathrm{NaPB}$ (data from [19]).

\begin{tabular}{|c|c|c|c|c|c|}
\hline Compound & $S_{S}$ & $A_{s}$ & $B_{S}$ & $C_{s}$ & $N ; \mathrm{SD} ; F^{\mathrm{c}}$ \\
\hline $\begin{array}{l}\text { Benzyl alcohol } \\
(\mathrm{NaCl}) \\
p \text {-values }^{\mathrm{b}}\end{array}$ & $-4.65 \pm 0.15$ & - & - & $0.98 \pm 0.01$ & $6 ; 0.006 ; 40747$ \\
\hline $\begin{array}{l}\text { Benzyl alcohol } \\
\text {-values }^{\text {b }}\end{array}$ & $\begin{array}{l}-2.9 \pm 0.55 \\
0.006\end{array}$ & - & $\begin{array}{l}1.1 \pm 0.33 \\
0.03\end{array}$ & $\begin{array}{l}1.3 \pm 0.1 \\
0.0002\end{array}$ & $7 ; 0.03 ; 1304$ \\
\hline $\begin{array}{l}\text { Caffeine }(\mathrm{NaCl}) \\
\text {-values }^{\mathrm{b}}\end{array}$ & $\begin{array}{l}2.2 \pm 0.85 \\
0.08\end{array}$ & $\begin{array}{l}9 \pm 2.8 \\
0.05\end{array}$ & $\begin{array}{l}-1.4 \pm 0.15 \\
0.003\end{array}$ & - & $6 ; 0.02 ; 836.1$ \\
\hline $\begin{array}{l}\text { Caffeine } \\
\text {-values }^{\mathrm{b}}\end{array}$ & - & - & $\begin{array}{l}0.3 \pm 0.1 \\
0.08\end{array}$ & $0.72 \pm 0.05$ & $7 ; 0.01 ; 2638$ \\
\hline $\begin{array}{l}\text { Coumarin }(\mathrm{NaCl}) \\
\text {-values }^{\mathrm{b}}\end{array}$ & $\begin{array}{l}-2.41 \pm 0.26 \\
0.003\end{array}$ & $\begin{array}{l}5.2 \pm 0.87 \\
0.009\end{array}$ & - & $1.34 \pm 0.02$ & $6 ; 0.005 ; 48324$ \\
\hline $\begin{array}{l}\text { Coumarin } \\
\text { Glucopyranoside }^{\mathrm{d}} \\
(\mathrm{NaCl}) \\
\text { p-values }\end{array}$ & $\begin{array}{l}- \\
-1.33 \pm 0.90 \\
0.1\end{array}$ & $\begin{array}{l}- \\
6.1 \pm 2 \\
0.05\end{array}$ & $\begin{array}{l}- \\
-1.49 \pm 0.10 \\
0.0007\end{array}$ & $\begin{array}{l}1.40 \pm 0.03 \\
-\end{array}$ & $\begin{array}{l}7 ; 0.05 ; 1673 \\
6 ; 0.01 ; 2909\end{array}$ \\
\hline $\begin{array}{l}\text { Glucopyranoside }^{\mathrm{d}} \\
\text {-values }^{\mathrm{b}}\end{array}$ & $\begin{array}{l}-1.4 \pm 0.4 \\
0.02\end{array}$ & - & - & $0.72 \pm 0.03$ & 7; 0.02; 1637 \\
\hline $\begin{array}{l}\text { Methyl } \\
\text { anthranilate }(\mathrm{NaCl}) \\
\text { p-values }^{\text {b }}\end{array}$ & $\begin{array}{l}-4.72 \pm 0.33 \\
0.005\end{array}$ & $\begin{array}{l}3.94 \pm 1.1 \\
0.07\end{array}$ & $\begin{array}{l}1.08 \pm 0.16 \\
0.02\end{array}$ & $\begin{array}{l}2.06 \pm 0.07 \\
0.001\end{array}$ & $6 ; 0.006 ; 35509$ \\
\hline $\begin{array}{l}\text { Methyl } \\
\text { anthranilate } \\
\text {-values }^{\text {b }}\end{array}$ & $\begin{array}{l}-3 \pm 0.82 \\
0.02\end{array}$ & - & $\begin{array}{l}1.7 \pm 0.49 \\
0.02\end{array}$ & $\begin{array}{l}2.1 \pm 0.16 \\
0.0002\end{array}$ & $7 ; 0.04 ; 1366$ \\
\hline $\begin{array}{l}\text { Phenol }(\mathrm{NaCl}) \\
\text {-values }^{\mathrm{b}}\end{array}$ & $-6.61 \pm 0.21$ & - & $\begin{array}{l}0.71 \pm 0.17 \\
0.03\end{array}$ & $\begin{array}{l}1.57 \pm 0.07 \\
0.0002\end{array}$ & $6 ; 0.007 ; 28494$ \\
\hline $\begin{array}{l}\text { Phenol } \\
p \text {-values }^{\text {b }}\end{array}$ & $\begin{array}{l}-3.8 \pm 0.48 \\
0.001\end{array}$ & - & $\begin{array}{l}1 \pm 0.99 \\
0.025\end{array}$ & $1.51 \pm 0.09$ & $7 ; 0.02 ; 2839$ \\
\hline $\begin{array}{l}\text { 2-Phenylethanol } \\
(\mathrm{NaCl}) \\
\text { p-values }^{\mathrm{b}}\end{array}$ & $-5.65 \pm 0.05$ & - & $\begin{array}{l}0.67 \pm 0.04 \\
0.0005\end{array}$ & $1.37 \pm 0.02$ & $6 ; 0.002 ; 380735$ \\
\hline $\begin{array}{l}\text { 2-Phenylethanol } \\
\text {-values }^{\mathrm{b}}\end{array}$ & $\begin{array}{l}-2.4 \pm 0.87 \\
0.04\end{array}$ & - & - & $1.09 \pm 0.07$ & $7 ; 0.05 ; 818$ \\
\hline $\begin{array}{l}\text { Vanillin }(\mathrm{NaCl}) \\
\text {-values }^{\mathrm{b}}\end{array}$ & $\begin{array}{l}-8.07 \pm 1.1 \\
0.005\end{array}$ & 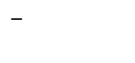 & $\begin{array}{l}2.6 \pm 0.9 \\
0.06\end{array}$ & $\begin{array}{l}2.43 \pm 0.38 \\
0.008\end{array}$ & $6 ; 0.04 ; 1233$ \\
\hline $\begin{array}{l}\text { Vanillin } \\
p \text {-values }\end{array}$ & $\begin{array}{l}-3 \pm 4 \\
0.1\end{array}$ & - & $\begin{array}{l}1.5 \pm 0.85 \\
0.1\end{array}$ & $\begin{array}{l}1.9 \pm 0.27 \\
0.002\end{array}$ & $7 ; 0.07 ; 382$ \\
\hline DNP-Ala $\mathrm{Na}(\mathrm{NaCl})$ & $-0.5 \pm 0.1$ & $2.01 \pm 0.31$ & $0.39 \pm 0.05$ & $1.39 \pm 0.02$ & $6 ; 0.002 ; 166699$ \\
\hline $\begin{array}{l}p \text {-values }^{b} \\
\text { DNP-Ala Na } \\
\text {-values }^{b}\end{array}$ & $\begin{array}{l}0.04 \\
-0.5 \pm 0.14 \\
0.03\end{array}$ & $\begin{array}{l}0.02 \\
-\end{array}$ & $\begin{array}{l}0.01 \\
0.52 \pm 0.08 \\
0.004\end{array}$ & $\begin{array}{l}0.0002 \\
1.39 \pm 0.03\end{array}$ & $7 ; 0.007 ; 23785$ \\
\hline $\begin{array}{l}\text { DNP-NVal Na } \\
(\mathrm{NaCl}) \\
\text {-values }^{\mathrm{b}}\end{array}$ & $\begin{array}{l}-2.4 \pm 0.39 \\
0.003\end{array}$ & - & - & $1.41 \pm 0.3$ & $6 ; 0.01 ; 8231$ \\
\hline $\begin{array}{l}\text { DNP-NVal Na } \\
p_{\text {-values }}^{\text {b }}\end{array}$ & $\begin{array}{l}-1.5 \pm 0.31 \\
0.009\end{array}$ & - & $\begin{array}{l}0.8 \pm 0.18 \\
0.01\end{array}$ & $1.67 \pm 0.06$ & $7 ; 0.01 ; 7372$ \\
\hline $\begin{array}{l}\text { DNP-NLeu Na } \\
(\mathrm{NaCl}) \\
p \text {-values }^{\mathrm{b}}\end{array}$ & $\begin{array}{l}-2.5 \pm 0.38 \\
0.003\end{array}$ & - & - & $1.65 \pm 0.03$ & $6 ; 0.01 ; 11183$ \\
\hline $\begin{array}{l}\text { DNP-NLeu Na } \\
p \text {-values }{ }^{\text {b }}\end{array}$ & $\begin{array}{l}-1.7 \pm 0.56 \\
0.04\end{array}$ & - & $\begin{array}{l}1 \pm 0.3 \\
0.04\end{array}$ & $1.9 \pm 0.1$ & $7 ; 0.03 ; 2876$ \\
\hline $\begin{array}{l}\text { DNP-AO Na }(\mathrm{NaCl}) \\
\text {-values }^{\mathrm{b}}\end{array}$ & $\begin{array}{l}-2.95 \pm 0.63 \\
0.02\end{array}$ & $\begin{array}{l}6.6 \pm 2.1 \\
0.05\end{array}$ & - & $2.00 \pm 0.05$ & $6 ; 0.01 ; 16774$ \\
\hline $\begin{array}{l}\text { DNP-AO Na } \\
p_{\text {-values }}{ }^{b}\end{array}$ & $\begin{array}{l}-2.8 \pm 0.73 \\
0.02\end{array}$ & - & $\begin{array}{l}2.1 \pm 0.44 \\
0.009\end{array}$ & $2.7 \pm 0.14$ & $7 ; 0.03 ; 2774$ \\
\hline
\end{tabular}

a Solute specific coefficients represent the following solute-water interactions: $S_{s}$-dipole-dipole interactions; $A_{s}-$ hydrogen bonding with solute as a donor; $B_{s}-$ hydrogen bonding with solute as an acceptor; $C_{s}$-induced dipole-ion interactions.

b Statistical significance $p$-value (not shown for $p<0.0001$ ).

c $N$-number of experimental data (partition coefficients under different conditions, including $K=1$ when properties of the phases are identical (see in text); SD-standard deviation; $F$-ratio of variance.

d $p$-Nitrophenyl- $\alpha$-D-glucopyranoside.

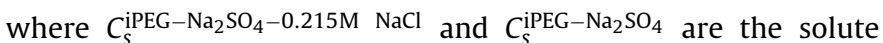
specific coefficients $S_{S}$ for $i$ th organic compound determined in
For sodium salts of DNP-amino acids the $\mathrm{NaCl}$ effect is not as strong as shown by the relationship in Fig. 8 described as:

$$
\begin{gathered}
C_{S}^{\mathrm{DNP}-\mathrm{aa} P E G-\mathrm{Na}_{2} \mathrm{SO}_{4}-0.215 \mathrm{M} \mathrm{NaCl}}=0.67_{ \pm 0.14}+0.49_{ \pm 0.08} \times C_{S}^{\mathrm{DNP}-\mathrm{aa} \mathrm{PEG}-\mathrm{Na}_{2} \mathrm{SO}_{4}} \\
N=4 ; \quad r^{2}=0.9586 ; \quad \mathrm{SD}=0.07 ; \quad F=46.4
\end{gathered}
$$

PEG- $\mathrm{Na}_{2} \mathrm{SO}_{4}-0.215 \mathrm{M} \mathrm{NaCl}$ and PEG-Na $\mathrm{SO}_{4}$ ATPS, correspondingly; all the other parameters are as defined above. It should be mentioned that 2-phenylethanol and methyl anthranilate do not fit the relationship and are considered to be outliers. The relationship seems to hold for nonionic compounds only. where superscript DNP-aa denotes DNP-amino acids Na-salts; all the other parameters are as defined above. It may be suggested that the small $\mathrm{NaCl}$ effect on the solute-specific coefficient $C_{S}$ for the charged compounds is due to the influence of the $\mathrm{NaCl}$ additive on the ionic compositions of the two phases [17], and in this 


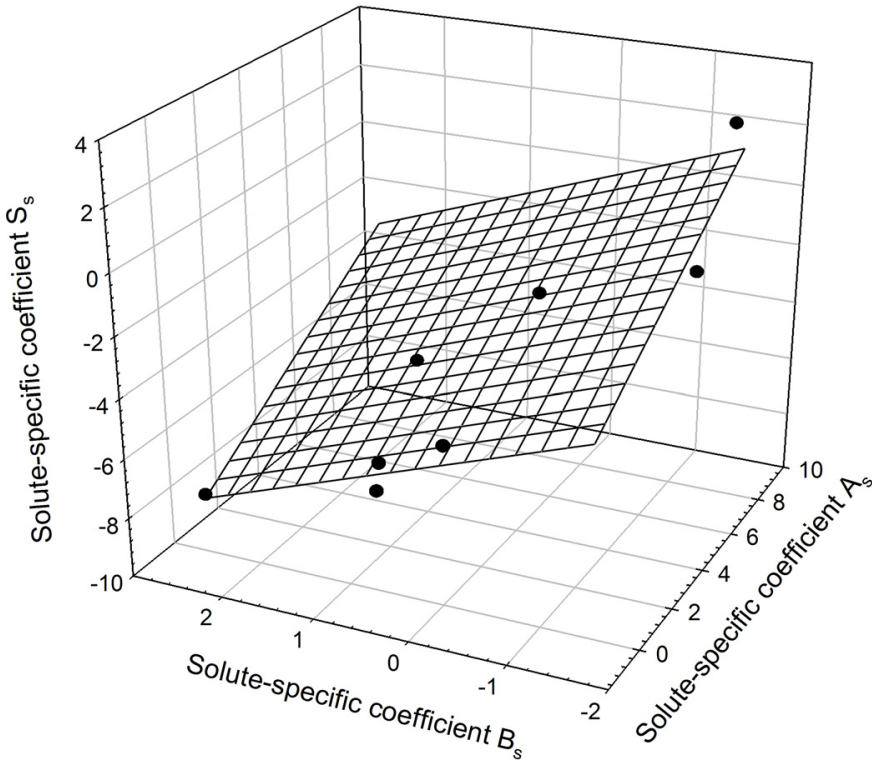

Fig. 9. Interrelationship between solute specific coefficients $S_{s}$, solute-specific coefficients $A_{s}$, and solute-specific coefficients $B_{s}$ for organic compounds determined in the presence of $0.215 \mathrm{M} \mathrm{NaCl}$. Solute-specific coefficient $S_{S}$ represents the contribution of dipole-dipole and dipole-induced dipole interactions between a given compound and aqueous media in the phases into solute partition coefficient, the solute-specific coefficient $A_{s}$ represents the contribution of hydrogen-bond interactions between the compound and solvent for compound playing the role of $\mathrm{H}$-bond donor into the solute partition coefficient, and the solute-specific coefficient $B_{s}$ represents the contribution of hydrogen-bond interactions between the compound and solvent for compound playing the role of $\mathrm{H}$-bond acceptor into the solute partition coefficient.

case it should be $\mathrm{NaCl}$ concentration dependent. Additional experiments at different $\mathrm{NaCl}$ additive concentrations are clearly needed to verify this assumption.

It has been reported $[19,25]$ recently that there seems to be a cooperativity between the different types of solute-water interactions due to which the solute-specific coefficients are linearly interrelated. The interrelationship between the solute-specific coefficients presented in Table 4 is illustrated graphically in Fig. 9, and it may be described as:

$$
\begin{aligned}
& S_{S}^{i}=-5.3_{ \pm 0.5}-1.1_{ \pm 0.31} \times A_{S}^{i}+0.6_{ \pm 0.12} \times B_{S}^{i} \\
& N=8 ; \quad r^{2}=0.9607 ; \quad \mathrm{SD}=0.77 ; \quad F=61.1
\end{aligned}
$$

where $B_{s}^{i}, C_{s}$, and $S_{s}^{i}$ are solute-specific coefficients for the $i$ th compound; all the other parameters are as defined above.

Similar interrelationship is presented in Fig. 10 and it may be described as:

$$
B_{S}^{i}=-1.8_{ \pm 0.15}-0.16_{ \pm 0.05} \times S_{S}^{i}+1.1_{ \pm 0.14} \times C_{S}^{i}
$$$$
N=7 ; \quad r^{2}=0.9861 ; \quad \mathrm{SD}=0.17 ; \quad F=141.9
$$

where $B_{s}{ }_{s}, C_{s}$, and $S_{s}{ }_{s}$ are solute-specific coefficients for the $i$ th compound; all the other parameters are as defined above. It should be noted that the data for caffeine do not fit the relationship.

The above data indicate that the $\mathrm{NaCl}$ additive in PEG- $\mathrm{Na}_{2} \mathrm{SO}_{4}$ ATPS does affect the solute-solvent interactions for organic compounds. The effects of the additive on the partition behavior of proteins seem to indicate it would affect the protein-solvent interactions even more.

\subsection{Protein-water interactions in PEG-sodium sulfate ATPS}

The solute-specific coefficients for proteins presented in Table 5 indicate that the effect of $\mathrm{NaCl}$ additive is protein specific. As an

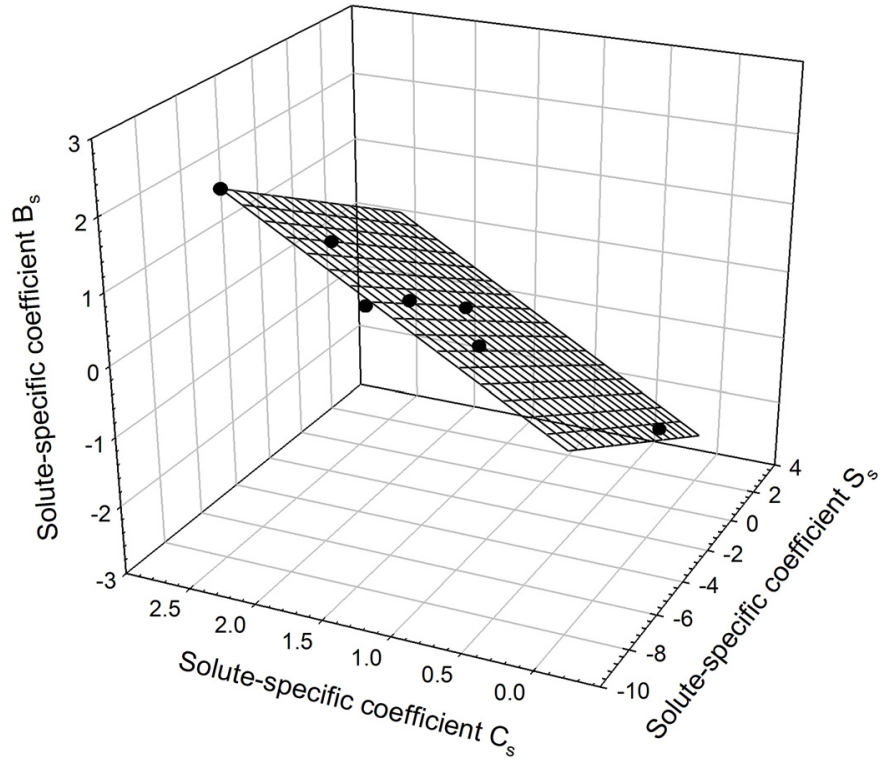

Fig. 10. Interrelationship between solute-specific coefficients $B_{S}$ for organic compounds and solute-specific coefficients $S_{s}$ and $C_{S}$ for the same compounds determined in the presence of $0.215 \mathrm{M} \mathrm{NaCl}$. Solute-specific coefficient $S_{s}$ represents the contribution of dipole-dipole and dipole-induced dipole interactions between a given compound and aqueous media in the phases into the solute partition coefficient, the solute-specific coefficient $B_{S}$ represents the contribution of hydrogen-bond interactions between the compound and solvent for compound playing the role of $\mathrm{H}$ bond acceptor into the solute partition coefficient, and the solute-specific coefficient $C_{s}$ represents the contribution of electrostatic interactions between the compound and aqueous media in the phases into the solute partition coefficient.

example, in the presence of $0.215 \mathrm{M} \mathrm{NaCl}$ the solute specific coefficient $B_{S}$ for $\alpha$-chymotrypsin is displayed as change from -2.3 to 0 , and for lysozyme from 1.7 to 3.2. There seems to be no general trend in the $\mathrm{NaCl}$ effect on any of the solute-specific coefficients.

Nevertheless, proteins seem to demonstrate cooperativity of different types of solute-water interactions similar to that displayed by simple organic compounds. Analysis of the data in Table 5 shows that the linear relationship similar to the one established for organic compounds is observed for proteins as well. This relationship illustrated graphically in Fig. 11 may be described as:

$$
\begin{gathered}
B_{s}^{i}=-0.5_{ \pm 0.45}+0.20_{ \pm 0.07} \times S_{s}^{i}+0.9_{ \pm 0.25} \times C_{s}^{i} \\
N=6 ; \quad r^{2}=0.9092 ; \quad \mathrm{SD}=0.63 ; \quad F=15
\end{gathered}
$$

where all the parameters are as defined above. It should be noted that the regression coefficients in Eq. (16) have the same absolute values as those in Eq. (15) for organic compounds, but most of the proteins examined have some of the solute-specific coefficients with zero values. Hence the above equation should be viewed as describing the trend rather than the reliable relationship. More proteins must be examined in order to ensure that the relationship in question does exist.

It is of interest to note that the severity of the effect of $\mathrm{NaCl}$ addition on the partition behavior of globular proteins in PEG-sulfate ATPSs is correlated with the protein charge. This observation is illustrated by Fig. 12 that represents dependence of the $\mathrm{NaCl}$-induced change in the protein partition coefficient (calculated as $\log K_{\mathrm{NaCl}}-\log K$ ), where $K$ and $K_{\mathrm{NaCl}}$ correspond to the partition coefficients of a given protein in the absence and presence of $0.215 \mathrm{M} \mathrm{NaCl}$ ) on the protein charge at $\mathrm{pH} 6.8$ evaluated using the InCharge software from the Aptium Biologics Ltd. (Southampton, UK, http://aptum.dyndns.org/epiquest/ epiquest.dll/svc_charge). Fig. 12 clearly shows that the $\mathrm{NaCl}$ efficiency to modulate partition of a protein is dependent on the protein's net charge. Here, the addition of $\mathrm{NaCl}$ does not affect 
Table 5

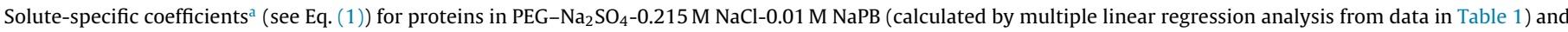
in PEG- $\mathrm{Na}_{2} \mathrm{SO}_{4}-0.01 \mathrm{M} \mathrm{NaPB}$ (data from [19]). NaPB-sodium phosphate buffer, pH 6.8.

\begin{tabular}{|c|c|c|c|c|c|}
\hline Protein & $S_{S}$ & $A_{s}$ & $B_{S}$ & $C_{s}$ & $N ; \mathrm{SD} ; F^{\mathrm{c}}$ \\
\hline 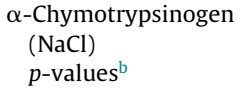 & $\begin{array}{l}3.3 \pm 1.4 \\
0.07\end{array}$ & $\begin{array}{l}-10.5 \pm 3.2 \\
0.03\end{array}$ & - & - & $6 ; 0.03 ; 373.2$ \\
\hline $\begin{array}{l}\alpha \text {-Chymotrypsinogen } \\
p \text {-values }^{\mathrm{b}}\end{array}$ & $\begin{array}{l}9.6 \pm 0.96 \\
0.04\end{array}$ & $\begin{array}{l}24 \pm 7.1 \\
0.03\end{array}$ & - & $\begin{array}{l}-1.2 \pm 0.21 \\
0.006\end{array}$ & 7; 0.04; 518 \\
\hline $\begin{array}{l}\text { Chymotrypsin }(\mathrm{NaCl}) \\
\text { p-values }^{\mathrm{b}}\end{array}$ & $\begin{array}{l}5.33 \pm 0.57 \\
0.003\end{array}$ & $\begin{array}{l}-17.3 \pm 1.9 \\
0.003\end{array}$ & - & $-1.21 \pm 0.04$ & $6 ; 0.01 ; 17401$ \\
\hline $\begin{array}{l}\text { Chymotrypsin } \\
p_{\text {-values }}{ }^{b}\end{array}$ & $\begin{array}{l}9.9 \pm 1.1 \\
0.003\end{array}$ & $\begin{array}{l}33.2 \pm 7.7 \\
0.02\end{array}$ & $\begin{array}{l}-2.3 \pm 0.5 \\
0.02\end{array}$ & $\begin{array}{l}-3.2 \pm 0.3 \\
0.001\end{array}$ & $7 ; 0.04 ; 1221$ \\
\hline $\begin{array}{l}\text { Concanavalin } \mathrm{A}(\mathrm{NaCl}) \\
p_{\text {-values }}{ }^{\mathrm{b}}\end{array}$ & $\begin{array}{l}4.49 \pm 0.78 \\
0.01\end{array}$ & - & $\begin{array}{l}-1.84 \pm 0.64 \\
0.06\end{array}$ & $-2.0 \pm 0.27$ & $6 ; 0.03 ; 1557$ \\
\hline $\begin{array}{l}\text { Concanavalin A } \\
\text { p-values }^{\mathrm{b}}\end{array}$ & $\begin{array}{l}2.4 \pm 1.1 \\
0.1\end{array}$ & - & $\begin{array}{l}-2.2 \pm 0.6 \\
0.03\end{array}$ & $\begin{array}{l}-1.9 \pm 0.2 \\
0.0007\end{array}$ & $7 ; 0.05 ; 469.8$ \\
\hline $\begin{array}{c}\text { Lipase }(\mathrm{NaCl}) \\
p \text {-values }\end{array}$ & $\begin{array}{l}0.82 \pm 0.14 \\
0.004\end{array}$ & - & - & $-0.44 \pm 0.01$ & $6 ; 0.005 ; 6087$ \\
\hline $\begin{array}{l}\text { Lipase } \\
\quad p \text {-values }^{\mathrm{b}}\end{array}$ & $\begin{array}{l}0.8 \pm 0.28 \\
0.04\end{array}$ & - & $\begin{array}{l}-0.4 \pm 0.17 \\
0.07\end{array}$ & $\begin{array}{l}-0.48 \pm 0.05 \\
0.0008\end{array}$ & $7 ; 0.01 ; 644.5$ \\
\hline $\begin{array}{l}\text { Lysozyme }(\mathrm{NaCl}) \\
p_{\text {-values }}{ }^{\mathrm{b}}\end{array}$ & $\begin{array}{l}12.7 \pm 0.9 \\
0.005\end{array}$ & $\begin{array}{l}24.2 \pm 2.9 \\
0.01\end{array}$ & $\begin{array}{l}3.16 \pm 0.43 \\
0.02\end{array}$ & $\begin{array}{l}1.24 \pm 0.19 \\
0.02\end{array}$ & $6 ; 0.02 ; 241.1$ \\
\hline $\begin{array}{l}\text { Lysozyme } \\
p_{\text {-values }}{ }^{\mathrm{b}}\end{array}$ & $\begin{array}{l}12 \pm 2.4 \\
0.005\end{array}$ & - & $\begin{array}{l}1.7 \pm 0.58 \\
0.04\end{array}$ & - & $7 ; 0.11 ; 174.8$ \\
\hline $\begin{array}{c}\text { Papain }(\mathrm{NaCl}) \\
p \text {-values }{ }^{\mathrm{b}}\end{array}$ & $\begin{array}{l}1.81 \pm 0.79 \\
0.05\end{array}$ & - & - & $\begin{array}{l}0.69 \pm 0.07 \\
0.0006\end{array}$ & $6 ; 0.03 ; 222.8$ \\
\hline $\begin{array}{l}\text { Papain } \\
\quad p \text {-values }\end{array}$ & $\begin{array}{l}4 \pm 2 \\
0.1\end{array}$ & $23 \pm 4.6$ & - & - & $7 ; 0.09 ; 36.2$ \\
\hline
\end{tabular}

a Solute specific coefficients represent the following solute-water interactions: $S_{s}$-dipole-dipole interactions; $A_{s}-$ hydrogen bonding with solute as a donor; $B_{s}-$ hydrogen bonding with solute as an acceptor; $C_{s}$-induced dipole-ion interactions.

b Statistical significance $p$-value (not shown for $p<0.0001$ ).

c $N$-number of experimental data (partition coefficients under different conditions, including $K=1$ when properties of the phases are identical (see in text); SD-standard deviation; F-ratio of variance.

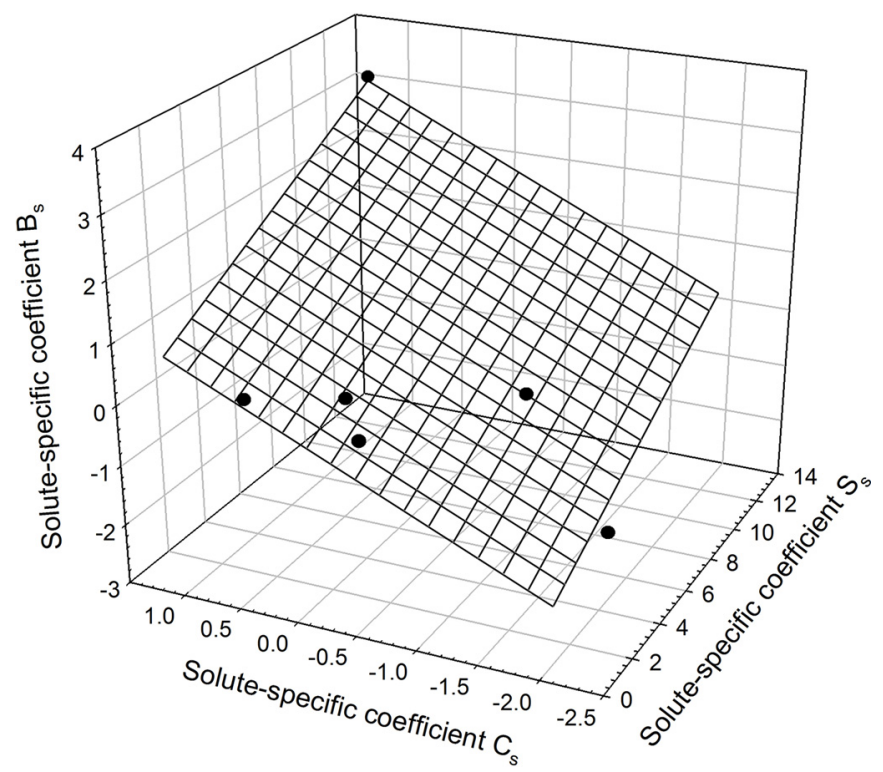

Fig. 11. Interrelationship between solute-specific coefficients $B_{S}$ for proteins and solute-specific coefficients $S_{S}$ and $C_{S}$ for the same proteins determined in the presence of $0.215 \mathrm{M} \mathrm{NaCl}$. Solute-specific coefficient $\mathrm{S}_{\mathrm{s}}$ represents the contribution of dipole-dipole and dipole-induced dipole interactions between a given compound and aqueous media in the phases into the solute partition coefficient, the solutespecific coefficient $B_{s}$ represents the contribution of hydrogen-bond interactions between the compound and solvent for compound playing the role of $\mathrm{H}$-bond acceptor into the solute partition coefficient, and the solute-specific coefficient $C_{s}$ represents the contribution of electrostatic interactions between the compound and aqueous media in the phases into the solute partition coefficient.

the behavior of the negatively charged proteins in the PEG-sulfate ATPS, whereas the partition of the positively-charged proteins in the same ATPS is strongly affected by $\mathrm{NaCl}$, suggesting the existence of some preferential binding of $\mathrm{Cl}^{-}$ions to the positively

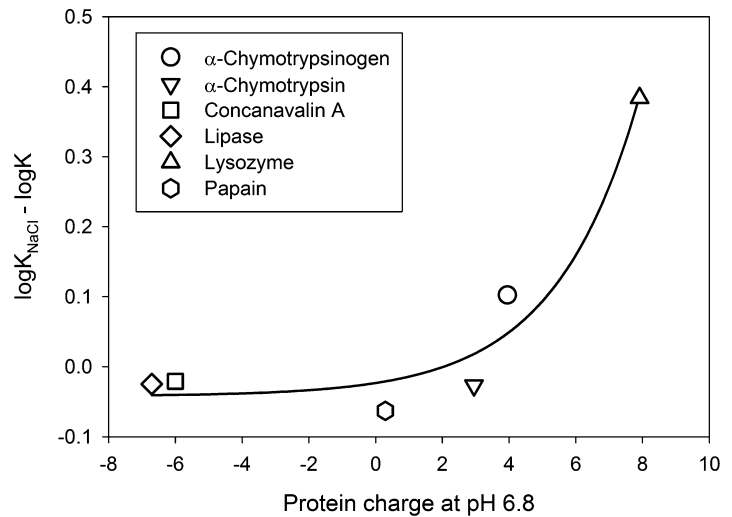

Fig. 12. Difference between logarithms of partition coefficients for proteins in the presence of $0.215 \mathrm{M} \mathrm{NaCl}$ and in the absence of $\mathrm{NaCl}$ additive in PEG-8000- $\mathrm{Na}_{2} \mathrm{SO}_{4}-$ $0.01 \mathrm{M}$ sodium phosphate buffer (NaPB), pH 6.8 ATPS as a function of the protein net charge at $\mathrm{pH}$ 6.8. The line is plotted for eye-guidance only.

charged proteins. Curiously, this preferential binding happens in the PEG-sulfate ATPS, which already contains a very high $\mathrm{Na}_{2} \mathrm{SO}_{4}$ concentration $\left(0.45 \mathrm{M}\right.$ overall, and $0.68 \mathrm{M} \mathrm{Na}_{2} \mathrm{SO}_{4}$ and $0.2 \mathrm{M} \mathrm{NaCl}$ in the bottom phase). In other words, $\mathrm{NaCl}$ seems to act as if no sulfate is present in the solution. This phenomenon can be explained using the results of earlier studies of Cremer's group, who, based on the analysis of interaction between Hofmeister ions with an uncharged 600 -residue elastin-like polypeptide, (VPGVG) 120 , revealed that $\mathrm{Cl}^{-}$binds to the amide nitrogen/ $\alpha$-carbon binding site, whereas $\mathrm{SO}_{4}{ }^{2-}$ was repelled from both the backbone and hydrophobic side chains of the polypeptide [26]. Additional experimental data indicating specificity of the effects of different ions on proteins and colloids are presented in the recent review by Salis and Ninham [27]. Although proteins analyzed in our study are expected to be differently charged in aqueous solutions, their charges are efficiently screened by high concentrations of sulfate, and 
therefore, they might behave similar to the aforementioned uncharged polypeptide, repelling $\mathrm{SO}_{4}{ }^{2-}$ and attracting $\mathrm{Cl}^{-}$. This preferential global attraction of the $\mathrm{Cl}^{-}$ions might create potential platform for the observed correlation between the effects of $\mathrm{NaCl}$ on partition behavior of globular proteins in PEG-sulfate ATPS and the protein charge in aqueous media.

It should be noted that the partition behavior of both small organic compounds and proteins in PEG- $\mathrm{Na}_{2} \mathrm{SO}_{4}-0.215 \mathrm{M} \mathrm{NaCl}$ ATPS can be described in terms of solute-solvent interactions.

The results of our study indicate that the solute-specific coefficients representing contributions of different types of solute-solvent interactions under the conditions explored differ from those determined in the absence of $\mathrm{NaCl}$ additive [19]. This fact confirms the previously suggested hypothesis $[23,25]$ that the solute-solvent interactions depend upon the solvent environment as well as upon the solute structure. Studies of the effects of different salt additives are necessary in order to better understand molecular mechanisms of these interactions, and these studies are currently in progress in our laboratories.

\section{Conclusions}

It is experimentally established that additive of $\mathrm{NaCl}$ affects partition behavior of small organic compounds and proteins in aqueous PEG- $\mathrm{Na}_{2} \mathrm{SO}_{4}$ two-phase system through its influence on the solute-water interactions. The data obtained agree with the assumption that polar organic compounds and proteins respond to their environment in aqueous media by changing contributions of different types of solute-water interactions in the solute- and ionic composition-specific manner.

\section{Acknowledgments}

Nuno da Silva acknowledges the financial support by Fundação para a Ciência e a Tecnologia (FCT) of the Portuguese's Ministry for Science, Technology and Higher Education, in the framework of the Operational Program COMPETE (PTDC/EQU-FTT/120332/2010) and Fundação para a Ciência e Tecnologia the strategic funding of UID/BIO/04469/2013.

Pedro P. Madeira acknowledges the financial support in part provided by (i) FCT/MEC, FEDER under Program PT2020 (Project UID/EQU/50020/2013) and (ii) QREN, ON2 and FEDER, under Program COMPETE (Project NORTE-07-0124-FEDER-0000011).

\section{References}

[1] R.R. Soares, A.M. Azevedo, J.M. Van Alstine, M.R. Aires-Barros, et al., Partitioning in aqueous two-phase systems: analysis of strengths, weaknesses, opportunities and threats, Biotechnol. J. 10 (8) (2015) 1158-1169.

[2] S.A. Oelmeier, F. Dismer, J. Hubbuch, Application of an aqueous twophasesystems high-throughput screening method to evaluate mAb HCP separation, Biotechnol. Bioeng. 108 (2011) 69-81.

[3] P. Diederich, M. Hoffmann, J. Hubbuch, High-throughput process developmentof purification alternatives for the protein avidin, Biotechnol. Prog. (2015), 〈http://dx.doi.org/10.1002/btpr.2104〉.

[4] B.A. Andrews, A.S. Schmidt, J.A. Asenjo, Correlation for the partition behavior of proteins in aqueous two-phase systems: effect of surface hydrophobicity and charge, Biotechnol. Bioeng. 90 (3) (2005) 380-390.
[5] A.M. Azevedo, P.A. Rosa, I.F. Ferreira, M.R. Aires-Barros, Optimisation of aqueous two-phase extraction of human antibodies, J. Biotechnol. 132 (2) (2007) 209-217.

[6] G. Bassani, P. Fucinos, G. Pico, B. Farruggia, Candida rugosa lipase Lip1polyethyleneglycol interaction and the relation with its partition in aqueous two-phase systems, Colloids. Surf., B: Biointerfaces 75 (2) (2010) 532-537.

[7] H. Cao, M. Yuan, L. Wang, J. Yu, F. Xu, Coupling purification and in situ immobilization process of monoclonal antibodies to clenbuterol for immunosensor application, Anal. Biochem. 476 (2015) 59-66.

[8] C.A. da Silva, J.S. Coimbra, E.E. Rojas, L.A. Minim, L.H. da Silva, Partitioning of caseinomacropeptide in aqueous two-phase systems, J. Chromatogr., B: Anal. Technol. Biomed. Life Sci. 858 (1-2) (2007) 205-210.

[9] R.L. de Souza, J.M. Barbosa, G.M. Zanin, M.W. Lobao, C.M. Soares, A.S. Lima et al., Partitioning of porcine pancreatic lipase in a two-phase systems of polyethylene glycol/potassium phosphate aqueous, Appl. Biochem. Biotechnol. $161(1-8)(2010) 288-300$.

[10] S.A. Oelmeier, F. Dismer, J. Hubbuch, Application of an aqueous two-phase systems high-throughput screening method to evaluate mAb HCP separation, Biotechnol. Bioeng. 108 (1) (2011) 69-81.

[11] T. Oshima, A. Suetsugu, Y. Baba, Extraction and separation of a lysine-rich protein by formation of supramolecule between crown ether and protein in aqueous two-phase system, Anal. Chim. Acta 674 (2)(2010) 211-219.

[12] R.L. Perez, D.B. Loureiro, B.B. Nerli, G. Tubio, Optimization of pancreatic trypsin extraction in PEG/citrate aqueous two-phase systems, Protein Expr. Purif. 106 (2015) 66-71.

[13] D.M. Pericin, S.Z. Madarev-Popovic, L.M. Radulovic-Popovic, Optimization of conditions for acid protease partitioning and purification in aqueous two-phase systems using response surface methodology, Biotechnol. Lett. 31 (1) (2009) 43-47.

[14] P.A. Rosa, S. Sommerfeld, A. Mutter, M.R. Aires-Barros, W. Backer, et al., Application of aqueous two-phase systems to antibody purification: a multi-stage approach, J. Biotechnol. 139 (4) (2009) 306-313.

[15] G. Tubio, G.A. Pico, B.B. Nerli, Extraction of trypsin from bovine pancreas by applying polyethyleneglycol/sodium citrate aqueous two-phase systems, J. Chromatogr., B: Anal. Technol. Biomed. Life Sci. 877 (3) (2009) 115-120.

[16] L.A. Ferreira, J.A. Teixeira, L.M. Mikheeva, A. Chait, B.Y. Zaslavsky, Effect of salt additives on partition of nonionic solutes in aqueous PEG-sodium sulfate twophase system, J. Chromatogr. A 1218 (2011) 5031-5039.

[17] L.A. Ferreira, P. Parpot, J.A. Teixeira, L.M. Mikheeva, B.Y. Zaslavsky, Effect of $\mathrm{NaCl}$ additive on properties of aqueous PEG-sodium sulfate two-phase system, J. Chromatogr. A 1220 (2012) 14-20.

[18] N.R. da Silva, L.A. Ferreira, L.M. Mikheeva, J.A. Teixeira, B.Y. Zaslavsky, Origin of salt additive effect on solute partitioning in aqueous polyethylene glycol8000-sodium sulfate two-phase system, J. Chromatogr. A 1337 (2014) 3-8, [22] B.Y.

[19] N.R. da Silva, L.A. Ferreira, P.P. Madeira, J.A. Teixeira, V. Uversky, B.Y. Zaslavsky, Analysis of partitioning of organic compounds and proteins in aqueous polyethylene glycol-sodium sulfate aqueous two-phase systems in terms of solute-solvent interactions, J. Chromatogr. A 1415 (2015) 1-10.

[20] B.Y. Zaslavsky, Aqueous Two-Phase Partitioning: Physical Chemistry and Bioanalytical Applications, CRC Press, New York, NY, 1994.

[21] J.G. Huddleston, H.D. Willauer, R.D. Rogers, The solvatochromic properties, $\alpha$ $\beta$, and $\pi^{*}$, of PEG-salt aqueous biphasic systems, Phys. Chem. Chem. Phys. 4 (2002) 4065-4070

[22] Y. Marcus, The properties of organic liquids that are relevant to their use as solvating solvents, Chem. Soc. Rev. 22 (1993) 409-416.

[23] L.A. Ferreira, P.P. Madeira, A.V. Uversky, V.N. Uversky, B.Y. Zaslavsky, Responses of proteins to different ionic environment are linearly interrelated, J. Chromatogr. A 1387 (2015) 32-41.

[24] M.A. Ab Rani, A. Brant, L. Crowhurst, A. Dolan, M. Lui, N.H. Hassan, J.P. Hallett, P.A. Hunt, H. Niedermeyer, J.M. Perez-Arlandis, M. Schrems, T. Welton, R. Wilding, Understanding the polarity of ionic liquids, Phys. Chem. Chem. Phys. 13 (2011) 16831-16840.

[25] P.P. Madeira, A. Bessa, J.A. Loureiro, L. Alvares-Ribeiro, A.E. Rodrigues, B.Y. Zaslavsky, Cooperativity between various types of polar solute-solvent interactions in aqueous media, J. Chromatogr. A 1408 (2015) 108-117.

[26] K.B. Rembert, J. Paterova, J. Heyda, C. Hilty, P. Jungwirth, P.S. Cremer, Molecula mechanisms of ion-specific effects on proteins, J. Am. Chem. Soc. 134 (2012) 10039-10046.

[27] A. Salis, B.W. Ninham, Models and mechanisms of Hofmeister effects in electrolyte solutions, and colloid and protein systems revisited, Chem. Soc. Rev. 43 (2014) 7358-7377. 